\title{
Debt Intolerance: Threshold Level and Composition
}

\author{
Hideaki Matsuoka
}

\section{Research Project on Central Bank Communication} 702 Faculty of Economics, The University of Tokyo,

7-3-1 Hongo, Bunkyo-ku, Tokyo 113-0033, Japan

Tel: +81-3-5841-5595 E-mail: watlab@e.u-tokyo.ac.jp

http://www.centralbank.e.u-tokyo.ac.jp/en/ 


\title{
Debt intolerance: Threshold level and composition*
}

\author{
Hideaki Matsuoka $^{\dagger}$
}

January, 2020

\begin{abstract}
Fiscal vulnerabilities depend on both the level and composition of government debt. This study investigates this threshold level of debt and its composition to understand the non-linear behavior of the long-term interest rate by developing a novel approach: a panel smooth transition regression with a general logistic model (i.e., a generalized panel smooth transition regression). Our main findings are threefold: (i) the impact of the expected public debt on the interest rate would increase exponentially and significantly as the foreign private holdings ratio exceeds approximately 20 percent; otherwise, strong home bias would mitigate the upward pressure of an increase in public debt on the interest rate; (ii) if the expected public debt-to-GDP ratio exceeds a certain level that depends on the funding source, an increase in foreign private holdings of government debt would cause a rise in long-term interest rates, offsetting the downward effect on long-term interest rates by expanding market liquidity; and (iii) out-of-sample forecast of our novel non-linear model is more accurate than those of previous methods. As such, the composition of government debt plays an important role in the highly non-linear behavior of the long-term interest rate.
\end{abstract}

Key Words: Generalized panel smooth transition regression, Expected public debt-to-GDP ratio, Foreign private investors, Long-term interest rate

JEL Codes: E43,E62,H63

*The views expressed herein are my own and do not represent those of World Bank. I thank the discussant Mototsugu Shintani at the 21st Macroeconomics Conference (Osaka, Japan). I am grateful for valuable comments from Serkan Arslanalp, Tamon Asonuma, Tran Lam Anh Duong, Hurlin Christophe, Ichiro Fukunaga, Nobuyuki Harada, Ryo Horii, Kazumasa Iwata, Munechika Katayama, Atsushi Kawamoto, Junko Koeda, Yoichi Matsubayashi, Ryota Nakatani, Boaz Nandwa, Futoshi Narita, Shin-Ichi Nishiyama, Masakatsu Okubo, Arito Ono, Jun Saito, Masaya Sakuragawa, Etsuro Shioji, Shigenori Shiratsuka, Kengo Tahara, Yuki Teranishi, Takayuki Tsuruga, Kozo Ueda and participants at Georgetown Center for Economic Research Biennial Conference, the 4th annual conference of the International Association for Applied Econometrics, Norges Bank Workshop on Nonlinear Models in Macroeconomics and Finance for an Unstable World, 28th annual meeting of the Midwest Econometrics Group, Dynamic Econometrics Conference (George Washington University) and seminars at Japan Center for Economic Research, Kobe University, Waseda University and University of Tsukuba. I also thank Mark Edgar Felsenthal for editorial assistance.

†World Bank, E-mail address:hmatsuoka@worldbank.org Postal address: 1818 H Street NW, MC2-204, Washington DC, 20433 USA /TEL:+1-202-473-8009. 
"The experiences of foreign economies suggest that the relationship between debt and interest rates is complex and likely non-linear, with the influence of greater debt on interest rates rising as the debt-to-GDP ratio reaches a trajectory at which investors have concerns about its sustainability."

-Brainard (2017)

"The level of debt that is sustainable in an economy is not a constant. It can change over time and indeed has changed enormously over the last 150 years. The ratio of credit to GDP in the late Victorian British economy was under 20 percent. In the mid-twentieth century it was around 60 percent and by the early 1990 s over 100 percent."

-Cunliffe (2019)

\section{Introduction}

As argued by Reinhart et al. (2003), fiscal vulnerabilities depend on both the level and composition (foreign vs. domestic) of government debt. They describe the "debt intolerance" phenomenon, in which interest rates in developing economies can spike above the "tolerance ceiling," even though the debt levels could be considered manageable by advanced country standards. Long-term interest rates in advanced economies have been lower than those in emerging markets although debt levels in advanced economies such as Japan, the United Kingdom and the United State are much higher than in emerging markets (Figures 1 and 2). While significant research has been devoted to estimating the marginal impact of public debt on long-term interest rates, there are different estimated impacts, even though they control for fundamental variables such as inflation expectations and growth rates $^{1}$. Meanwhile, the composition for government bond holding is heterogeneous across countries. The share of foreign private investors in emerging markets has been larger than advanced economies since the global financial crisis (Figure 3) $)^{2}$. Also, major central banks in advanced economies have been important players in the government bond markets, purchasing government bonds financed by the creation of central bank reserves through quantitative easing. This paper sheds light on the composition for government bond holdings (foreign vs. domestic or official vs. private) as well as its level to investigate the determinant of long-term yields.

\footnotetext{
${ }^{1}$ Please see Section 3.4 for details.

${ }^{2}$ According to Arslanalp and Tsuda (2014a), the average share of external public debt in local currency as a fraction of total external debt in 14 emerging markets increased from 24 percent in 2009Q4 to 42 percent in 2018Q2. To understand this recent dynamics, Ottonello and Perez (2019) develop a model of optimal choice of debt denominated in foreign and local currency and conclude that the prolonged economic expansion and stabilization of inflation during this period can account for most of the observed change in the currency composition of sovereign debt. By contrast, the temptation to reduce debt repayments in local currency through inflation is high in recessions since the marginal benefit of saving resources for consumption is high. To mitigate the higher incentives to dilute debt, the government optimally chooses to tilt its currency composition to foreign currency.
} 
Some maintain that foreign investors require higher risk premia than domestic ones when a government would likely repay domestic ones before foreign ones ${ }^{3}$. Azzimonti and Quadrini (2017) find that the integration of financial markets increases the incentives of a given country to default not only because part of the defaulted debt is owned by foreigners, but also because the macroeconomic cost of a default is smaller when the defaulting country is financially integrated. Gros (2013) and Ichiue and Shimizu (2015) also argue that if domestic financial institutions have a large share of government bonds, the losses they might incur would be large. To avoid this, governments would have a clear incentive to select fiscal consolidation rather than undergo default.

Empirically, Dell'Erba et al. (2013), Ichiue and Shimizu (2015) and Tenreyro (2019) conclude that when an increase in debt is financed through foreign borrowing, the increase in the interest rate is greater than when the increase is financed domestically ${ }^{4}$. Similarly, Agca and Celasun (2012) show that the impact of domestic public debt on the syndicated loan yield spreads is not statistically significant whereas that of external public debt is significant. Brzoza-Brzezina and Kotlowski (2018), using the panel smooth transition regression (PSTR) model developed by González et al. (2017), show that risk premia increases slowly with the worsening of the net financial assets positions, and then suddenly jump.

Meanwhile, Reinhart and Trebesch (2015) argue that an increase in the share of foreign investors is associated with lower long-term interest rates because these holdings supplement domestic saving in capital-scarce countries, especially in times of high global liquidity. Peiris (2013) describe that while domestic investors are typically buy-and-hold investors, foreign investors are more likely to trade. Some empirical studies support this downward effect (Arslanalp and Poghosyan (2016), Carvalho and Fidora (2015), Ebeke and Lu (2015) and

\footnotetext{
${ }^{3}$ This argument is based on the assumption that a government can default selectively on foreign investors. Erce and Mallucci (2018) find that selective defaults have existed and have been frequent over the period 1980-2015. Since 1980 about two-thirds of the defaults have selectively involved either foreign-law bonds or domestic-law bonds. By contrast, Sturzenegger and Zettelmeyer (2008) conclude that with a few exceptions, domestic investors do not appear to have been treated systematically better than foreign investors between 1998 and 2005. Broner et al. (2014) argue that selective default can happen when the government can impose capital controls to make it easier to discriminate. Meanwhile, Broner et al. (2010) show that secondary markets both reduce the probability of default on foreigners and make it difficult for the government to discriminate among creditors.

${ }^{4}$ Asonuma et al. (2015) also show that higher home bias mitigates the upward pressure of the increase in public debt on bond spreads, using three home bias indicators: (1) Banks' holding of domestic sovereign claims / Banks' total assets, (2) Banks' holding of domestic sovereign claims / Banks' holding of sovereign claims and (3) Banks' holding of domestic sovereign claims / Public debt of sovereign. Their result is line with the fiscal crisis model of Sakuragawa and Sakuragawa (2016) that explain why domestic investors do not require a risk premium against large outstanding debt when there is a strong home bias in the asset portfolio of domestic bondholders. The reason is that these investors turn out to have no access to any assets that hedge fiscal risk. Ongena et al. (2019) find that domestic banks, which had received government support in the past, as well as were smaller, less well capitalized, and had a lower ratio of liquid assets, were strongly more likely to purchase domestically issued sovereign debt than foreign banks when the government had to roll over a relatively large amount of sovereign debt in the acute phase of the European sovereign debt crisis.
} 
Warnock and Warnock (2009)). From another angle, Azzimonti et al. (2014) illustrates that small countries facing a larger world market relative to their own economies perceive the interest rate as less sensitive to their own debt in a globalized world since both the demand and supply of the government debt come out only from domestic investors and government but also from foreign sources.

Although a large body of literature shows both positive and negative impacts of an increase in the share of foreign debt on government bond yields, a reconciliation of these opposite impacts through an investigation of the threshold has received less attention. To investigate such a threshold, the non-linear technique also has not been examined well beyond a few studies. Our work is closely related to Ebeke and Lu (2015) and BrzozaBrzezina and Kotlowski (2018). Ebeke and Lu (2015) show that in emerging markets an increase in the share of foreign holdings has a negative impact on yield but if either the lagged external debt-to-GDP ratio exceeds 90 percent or the lagged short-term debt-to-GDP ratio exceeds 21.5 percent, the corresponding impacts turn positive. Brzoza-Brzezina and Kotlowski (2018) find that the country's risk premium is significantly large, as the net financial assets position goes below approximately 70-75 percent of GDP.

This paper contributes to two strands of literature, extending and complementing Ebeke and Lu (2015) and Brzoza-Brzezina and Kotlowski (2018). First, an important methodological contribution is made with regard to the generalized panel smooth transition regression (GPSTR) model by combining two approaches: the panel smooth transition regression (PSTR) and the general logistic model (GLM). Ebeke and Lu (2015) and Brzoza-Brzezina and Kotlowski (2018) employ the interaction-term (IT) and PSTR models, respectively ${ }^{5}$. The most different point between GPSTR model and the previous methods differ most in that GPSTR model can investigate the potential point asymmetry whereas the IT and PSTR models exhibit point symmetry. If the impact of an increase in expected public debts on the interest rate is highly non-linear, our novel model can improve the estimation. We evaluate the performance of GPSTR model by comparing the out-of-sample forecast error with those of other methods employed in previous studies.

Second, we simultaneously estimate two types of threshold values to address the following questions :

(i) What is the threshold at which the share of foreign private investors triggers a surge in government bond

\footnotetext{
${ }^{5}$ The motivation of Brzoza-Brzezina and Kotlowski (2018) in employing the PSTR model is that the dynamic stochastic general equilibrium (DSGE) literature such as Schmitt-Grohe and Uribe (2003), Adolfson et al. (2007) and García-Cicco et al. (2010) assumes a nonlinear (e.g., exponential) relationship between risk premia and foreign debt. As these DSGE studies do not assume that the government has the public debt, the country risk premium used in these studies does not necessarily represent the sovereign risk premium. However, since Brzoza-Brzezina and Kotlowski (2018) use the difference between a country's long-term interest rate and the United States as a proxy for country risk premium as well as the PSTR model, their study is the most closely related to ours.
} 
yields through the increase in the public debt?

(ii) What is the threshold at which the level of public debt triggers a surge in government bond yields through the increase in the share of private foreign investors?

Ebeke and Lu (2015) and Brzoza-Brzezina and Kotlowski (2018) investigate only one kind of threshold, whereas we investigate two types of threshold values simultaneously ${ }^{6}$.

The remainder of this paper is organized as follows. Section 2 examines non-linear models: the IT, PSTR and GPSTR models to explore the threshold values, using forecast data that includes 11 advanced economies and 14 emerging markets. Section 3 shows the baseline estimation results, the model evaluation, and comparison with other studies. The conclusion is provided in Section 4.

\section{Empirical strategy and data}

Local currency bonds are held by both domestic and foreign investors, whereas foreign currency bonds can be assumed to be held by only foreign investors. To estimate the threshold of the composition for government bond holdings (foreign vs. domestic), we employ local currency bond yields because they reflect the behavior of both domestic and foreign investors ${ }^{7}$. We examine three models, namely, the (i) Interaction term model (IT), (ii) Panel Smooth Transition Regression (PSTR), and (iii) Generalized Panel Smooth Transition Regression (GPSTR) models.

The (i) IT model is a simple specification with the interaction term between the share of foreign private investors and the expected public debt. The (ii) PSTR model, developed by González et al. (2017) and Fok et al. (2005), includes the standard logistic function that exhibits point symmetry with one slope parameter and one location parameter. Brzoza-Brzezina and Kotlowski (2018) is relevant to our empirical strategy because they employ the PSTR model to examine a nonlinear relationship between a country's risk premium and the

\footnotetext{
${ }^{6}$ These two previous studies use the actual debt data, whereas we use a wide range of forecast data to omit any other effects of current economic conditions on the interest rates as well as consider the forward looking behavior of the financial markets.

${ }^{7}$ Ebeke and Lu (2015) and Brzoza-Brzezina and Kotlowski (2018), who also use local currency bonds in emerging markets, control for the exchange rate risk whereas Moore et al. (2013) does not control for it directly but does so indirectly, estimating the share of foreign investors that is affected by the exchange rate risk. We examine both cases including the exchange rate risk for the baseline estimate and excluding it for the robustness check. Amstad et al. (2020), using the average credit ratings provided by Standard and Poor's, Moody's and Fitch find a slow and steady convergence of soverign risk in local and foreign currency due to higher availability of foreign currency via FX reserves and lesser dependence on foreign currency borrowing (decline of original sin) over the past 20 years.
} 
net financial assets. To grasp the potential point asymmetry, this paper develops the (iii) GPSTR model by replacing the standard logistic function employed by González et al. (2017) with GLM, as suggested by Stukel (1988).

\subsection{Interaction term (IT)}

We examine how the interaction term between the share of foreign private investors and the expected public debt affects the interest rate as follows:

$$
\mathbb{E}_{t} L_{i, t+n}=\alpha_{i}+\beta_{0} \mathbb{E}_{t} D_{e b t_{i, t+n}}+\beta_{1} \mathbb{E}_{t} D_{e b t_{i, t+n}} \cdot f p_{i, t-1}+\delta f p_{i, t-1}+\phi \mathbf{z}_{\mathbf{i}, \mathbf{t}}+\varepsilon_{i, t}
$$

where a country $i=1, \ldots, N$ at a time $t=1, \ldots, T, \mathbb{E}_{t} L_{i, t+n}$ is the $n$-year-ahead forward long-term interest rate, $\mathbb{E}_{t} D e b t_{i, t+n}$ is the $n$-year-ahead projection for the public debt (percent of GDP), $f p_{i, t-1}$ is lagged share of private foreign investors and $\mathbf{z}_{\mathbf{i t}}$ describes control variables ${ }^{8}$. We analyze the effect of forward-looking projections of public debt on the forward interest rates to omit any effects of current economic conditions. As discussed by Engen and Hubbard (2005), Ichiue and Shimizu (2015) and Laubach (2009), when a deterioration of fiscal conditions and a decrease in the interest due to the expected accommodative monetary policy occur simultaneously during a recession, the upward effect of fiscal deterioration on the long-term interest rates could be underestimated even if we control for other variables. In addition, the government bond yield is influenced by forward-looking variables. $\beta_{1}$ is expected to be larger than $\beta_{0}$ : domestic investors may not require a risk premium against large debt when there is strong home bias without any other assets hedging fiscal risk. $\delta$ is expected to be negative: while domestic investors are typically buy-and-hold investors, foreign investors are more likely to trade. This could be supportive of increased market liquidity.

\subsection{PSTR and GPSTR}

The PSTR model, developed by González et al. (2017) and Fok et al. (2005) can be used to allow for a continuum of regimes, each one being characterized by a different value of the transition variable. Replacing

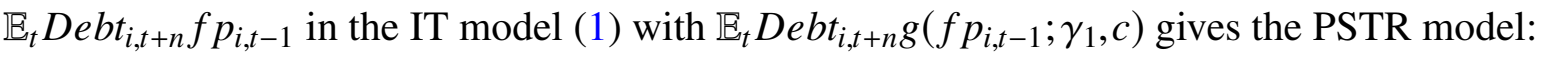

\footnotetext{
${ }^{8}$ We take a lagged value of foreign investors to avoid a simultaneity bias because the interest rate affects their behaviors. We discuss this endogeneity in Section 3.2.
} 


$$
\mathbb{E}_{t} L_{i, t+n}=\alpha_{i}+\beta_{0} \mathbb{E}_{t} \operatorname{Debt}_{i, t+n}+\beta_{1} \mathbb{E}_{t} \operatorname{Debt}_{i, t+n} \cdot g\left(f p_{i, t-1} ; \gamma_{1}, c\right)+\delta f p_{i, t-1}+\phi \mathbf{z}_{\mathbf{i}, \mathbf{t}}+\varepsilon_{i, t}
$$

where $g\left(f p_{i, t-1} ; \gamma_{1}, c\right)$ is the standard logistic function $\left(\frac{1}{1+\exp \left(-\gamma_{1}\left(f p_{i, t-1}-c\right)\right)}, \gamma_{1}>0\right)$ that depends on the threshold variable $f p_{i, t-1}$, the slope parameters $r_{1}$ and location parameters $c{ }^{9}$. This standard logistic function $g\left(f p_{i, t-1} ; \gamma_{1}, c\right)$ exhibits point symmetry with one slope parameter $r_{1}$. In other words, regardless of whether the threshold variable is larger or smaller than the location $c$, the impact of the public debt of all regimes could be affected by one slope parameter $r_{1}$. Figure 4 shows examples for the standard logistic function as well as the interaction term that exhibit point symmetry. To investigate potential point asymmetry, we introduce two slope parameters $\left(\gamma_{1}\right.$ and $\left.\gamma_{2}\right)$, replacing the standard logistic function with the general logistic model suggested by Stukel (1988).

The generalized panel smooth transition regression (GPSTR) is as follows:

$$
\mathbb{E}_{t} L_{i, t+n}=\alpha_{i}+\beta_{0} \mathbb{E}_{t} \text { Debt }_{i, t+n}+\beta_{1} \mathbb{E}_{t} \text { Debt }_{i, t+n} \cdot g\left(f p_{i, t-1} ; \gamma_{1}, \gamma_{2}, c\right)+\delta f p_{i, t-1}+\phi \mathbf{z}_{\mathbf{i}, \mathbf{t}}+\varepsilon_{i, t}
$$

Following Stukel (1988), the general logistic model (GLM), $g\left(f p_{i, t-1} ; \gamma_{1}, \gamma_{2}, c\right)$ is defined as follows:

$$
g\left(f p_{i, t-1} ; \gamma_{1}, \gamma_{2}, c\right)=\frac{\exp \left(h\left(f p_{i, t-1} ; \gamma_{1}, \gamma_{2}, c\right)\right)}{1+\exp \left(h\left(f p_{i, t-1} ; \gamma_{1}, \gamma_{2}, c\right)\right)}
$$

For $f p_{i, t-1}-c \leqslant 0$,

$$
h\left(f p_{i, t-1} ; \gamma_{1}, c\right)=\left\{\begin{array}{cc}
\gamma_{1}^{-1}\left(\log \left(1-\gamma_{1}\left|f p_{i, t-1}-c\right|\right)\right) & \gamma_{1}<0 \\
f p_{i, t-1}-c & \gamma_{1}=0 \\
-\gamma_{1}^{-1}\left(\exp \left(\gamma_{1}\left|f p_{i, t-1}-c\right|\right)-1\right) & \gamma_{1}>0
\end{array}\right.
$$

For $f p_{i, t-1}-c \geqslant 0$,

\footnotetext{
${ }^{9}$ When $r_{1} \rightarrow \infty$, PSTR model reduces to the two-regime panel threshold model by Hansen (1999).
} 


$$
h\left(f p_{i, t-1} ; \gamma_{2}, c\right)=\left\{\begin{array}{cc}
-\gamma_{2}^{-1}\left(\log \left(1-\gamma_{2}\left|f p_{i, t-1}-c\right|\right)\right) & \gamma_{2}<0 \\
f p_{i, t-1}-c & \gamma_{2}=0 \\
\gamma_{2}^{-1}\left(\exp \left(\gamma_{2}\left|f p_{i, t-1}-c\right|\right)-1\right) & \gamma_{2}>0
\end{array}\right.
$$

The transition functions $g\left(f p_{i, t-1} ; \gamma_{1}, \gamma_{2}, c\right)$ depend on the lagged share of private foreign investors $f p_{i, t-1}$, the slope parameters $r_{1}, r_{2}$ and location parameters $c$. Figure 5 shows examples for the GLM $g\left(f p_{i, t-1} ; \gamma_{1}, \gamma_{2}, c\right)$ that exhibit point asymmetry. The estimation of the parameters of the GPSTR model consists in eliminating the individual effects $\alpha_{i}$ by removing individual-specific means and then in applying non-linear least squares to the transformed model. The matrix of transformed explanatory variables is

$$
x^{*}\left(\gamma_{1}, \gamma_{2}, c\right)=\left[\mathbb{E}_{t} \widetilde{D_{e b t_{i, t+n}}}: \widetilde{G_{i, t+n}}: \widetilde{f p_{i, t-1}}: \widetilde{\mathbf{z}_{\mathbf{i}, \mathbf{t}}}\right]^{\prime}
$$

where $\widetilde{\mathbb{E}_{t} L_{i, t+n}}=\mathbb{E}_{t} L_{i, t+n}-\overline{L_{i}}, \mathbb{E}_{t} \overline{\operatorname{Debt}_{i, t+n}}=\mathbb{E}_{t}$ Debt $_{i, t+n}-\overline{D e b t}_{i}, \widetilde{f p_{i, t-1}}=f p_{i, t-1}-\overline{f p_{i}}$ and $\widetilde{\mathbf{z}_{\mathbf{i}, \mathbf{t}}}=\mathbf{z}_{\mathbf{i}, \mathbf{t}}-\overline{\mathbf{z}_{\mathbf{i}}}$. $\widetilde{G_{i, t+n}}\left(\gamma_{1}, \gamma_{2}, c\right)=\mathbb{E}_{t} \widetilde{D^{2} b t_{i, t+n}} \cdot g\left(f p_{i, t-1} ; \gamma_{1}, \gamma_{2}, c\right)-\frac{1}{T} \sum_{t=1}^{T} \mathbb{E}_{t} D e b t_{i, t+n} \cdot g\left(f p_{i, t-1} ; \gamma_{1}, \gamma_{2}, c\right)$ is the transformed explanatory variables in the second regime that depends on the parameters and the transition function. Given a couple $\left(\gamma_{1}, \gamma_{2}, c\right)$, the parameters can be estimated by ordinary least squares, which yields:

$$
\widehat{\Psi}\left(\gamma_{1}, \gamma_{2}, c\right)=\left[\sum_{i=1}^{N} \sum_{t=1}^{T} x_{i, t}^{*}\left(\gamma_{1}, \gamma_{2}, c\right) x_{i, t}^{*}\left(\gamma_{1}, \gamma_{2}, c\right)^{\prime}\right]^{-1}\left[\sum_{i=1}^{N} \sum_{t=1}^{T} x_{i, t}^{*}\left(\gamma_{1}, \gamma_{2}, c\right) \widetilde{\mathbb{E}_{t} L_{i, t+n}}\right]
$$

where $\widehat{\Psi}\left(\gamma_{1}, \gamma_{2}, c\right)$ is conditional to the values $\left(\gamma_{1}, \gamma_{2}, c\right)$. For the next step, by increasing the number of combinations for $\left(\gamma_{1}, \gamma_{2}, c\right)$, the parameters of the transition function $\gamma_{1}, \gamma_{2}$ and $c$ are estimated by non-linear least squares :

$$
\left(\hat{\gamma}_{1}, \hat{\gamma}_{2}, \widehat{c}\right)=\underset{\left\{\gamma_{1}, \gamma_{2}, c\right\}}{\operatorname{ArgMin}} \sum_{i=1}^{N} \sum_{t=1}^{T}\left[\widetilde{\mathbb{E}_{t} L_{i, t+n}}-\widehat{\Psi}^{\prime}\left(\gamma_{1}, \gamma_{2}, c\right) x^{*}\left(\gamma_{1}, \gamma_{2}, c\right)\right]
$$

Consequently, $\left(\hat{\beta}_{0}: \hat{\beta}_{1}: \widehat{\delta}: \widehat{\phi}\right)^{\prime}=\widehat{\Psi}\left(\hat{\gamma}_{1}, \hat{\gamma}_{2}, \widehat{c}\right)$.

The practical computation follows two steps.

- Step1. The initial values can be obtained by starting a grid search across the parameters $\gamma_{1}, \gamma_{2}$ and $c$ where grid points are $n_{\gamma_{1}}=21 n_{\gamma_{2}}=21$ and $n_{c}=30$. Hence, the number of regressions is 13,230 . 
- Step2. We employ the Nelder-Mead simplex algorithm to find a local minimizer of the function nonlinear least squares, using the initial values ${ }^{10}$.

\subsection{Threshold level and composition}

Using estimated parameters and solving $\frac{\partial \mathbb{E}_{t} L_{i, t+n}}{\partial \mathbb{E}_{t} D e b t_{i, t+n}}=0$ and $\frac{\partial \mathbb{E}_{t} L_{i, t+n}}{\partial f p_{i, t-1}}=0$ can address the following two questions:

1. What is the threshold at which the share of foreign investors triggers a surge in government bond yields through an increase in the expected public debt?

2. What is the threshold at which the level of public debt triggers a surge in government bond yields through an increase in the share of foreign investors?

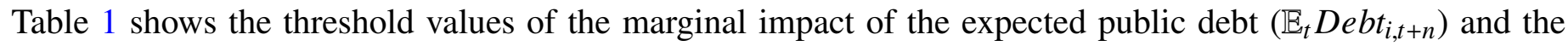
share of foreign private investors $\left(f p_{i, t-1}\right)$ on the interest rate.

The first column shows the share of foreign private investors $f p_{i, t-1}$ that triggers a surge in government bond yields through an increase in the expected public debt. Such threshold values depend on the ratio of the first regime parameter of the expected public debt $\left(\beta_{0}\right)$ to the second regime parameter of the expected public $\operatorname{debt}\left(\beta_{1}, \beta_{1}\left(f p_{i, t-1} ; \gamma_{1}, c\right)\right.$ or $\left.\beta_{1}\left(f p_{i, t-1} ; \gamma_{1}, \gamma_{2}, c\right)\right)$.

The second column shows the expected public debt $\mathbb{E}_{t} D_{e b t_{i, t+n}}$ that triggers a surge in government bond yields through an increase in the share of foreign investor ${ }^{11}$ The threshold of the expected public debt becomes smaller if investors are more sensitive to the expected public debt. As a result, an increase in foreign private holdings of government debt would cause an increase in long-term interest rates, offsetting the downward effect on long-term interest rates by expanding market liquidity, even if foreign investors can be supportive of increased market liquidity.

\footnotetext{
${ }^{10}$ This algorithm uses a simplex of $n+1$ points for $n$-dimensional vectors and discards the current worst point to reduce difference between the current best point and other points in simplex at each step in the iteration. See Lagarias et al. (1998) and Miranda and Fackler (2002) for details. Computational codes are based on Colletaz and Hurlin (2006) and Fouquau et al. (2008).

${ }^{11}$ See Appendix A.2 for the derivatives of the transition function $g\left(f p_{i, t-1} ; \gamma_{1}, \gamma_{2}, c\right)$.
} 
Table 1: Estimated threshold values of the impact of the increase in the share of foreign private investors $\left(f p_{i, t-1}\right)$ and the expected public debt $\left(\mathbb{E}_{t} D e b t_{i, t+n}\right)$ on the interest rate

\begin{tabular}{|c|c|c|}
\hline & Threshold composition & Threshold level \\
\hline (1) IT & $f p_{i, t-1}=\frac{-\beta_{0}}{\beta_{1}}$ & $\mathbb{E}_{t} D_{e} b t_{i, t+n}=\frac{-\delta}{\beta_{1}}$ \\
\hline (2) PSTR & $f p_{i, t-1}=\frac{-\beta_{0}}{\beta_{1}\left(f p_{i, t-1} ; \gamma_{1}, c\right)}$ & $\mathbb{E}_{t}$ Debt $_{i, t+n}=\frac{-\delta}{\beta_{1}\left\{\frac{\partial g\left(f p_{i, t-1} ; \gamma_{1}, c\right)}{\partial f p_{i, t-1}}\right\}}$ \\
\hline (3) GPSTR & $f p_{i, t-1}=\frac{-\beta_{0}}{\beta_{1}\left(f p_{i, t-1} ; \gamma_{1}, \gamma_{2}, c\right)}$ & $\mathbb{E}_{t}$ Debt $_{i, t+n}=\frac{-\delta}{\beta_{1}\left\{\frac{\partial g\left(f p_{i, t-1} ; \gamma_{1}, \gamma_{2}, c\right)}{\partial f p_{i, t-1}}\right\}}$ \\
\hline
\end{tabular}

\subsection{Data}

\subsubsection{Data coverage}

Considering forecast data availability, we use the data of 25 countries: 11 advanced economies and 14 emerging markets during 2006H2-2018H2 (data frequency : bi-annual) . Advanced economies include Australia, Canada, the Czech Republic, Denmark, Japan, Korea, Norway, Sweden, Switzerland, the United Kingdom, and the United States. Emerging markets include Bulgaria, Columbia, China, Hungary, India, Indonesia, Malaysia, Mexico, Peru, the Philippines, Poland, Thailand, Turkey, and South Africa. The Euro area countries are omitted from advanced economies for the following reasons. As discussed by Ichiue and Shimizu (2015) and Wright (2011), this is because their term structures had been highly correlated with those of Germany since the introduction of the euro. Therefore, it would be difficult to identify how much long-term interest rates in the Euro area have reflected the fundamentals of these countries. In this regard, the share of foreign private investors in the Euro area has been relatively higher than others (Arslanalp and Tsuda (2014a)). In the Euro area, the zero percent risk weight has been a major driver of banks' holdings of foreign debt securities denominated in the local currency due to the capital regulation by Basel. Bonner (2016) show that capital regulation encourages banks to substitute other bonds with government bonds. Because of this regulatory impact, the impact of foreign investors on the interest rates for the Euro area could be different from that of other countries. Hence, Euro area countries are omitted ${ }^{12}$.

\footnotetext{
${ }^{12}$ Brzoza-Brzezina and Kotlowski (2018) employing the PSTR model also use data from both advanced economies and emerging markets. However, they use actual data, not forecast data
} 


\subsubsection{Forward interest rates}

We use forward interest rates instead of current bond yields as a dependent variable. According to Shiller et al. (1983), the $m$-to- $m+n$-year forward nominal interest rate $\mathbb{E}_{t} L_{i, t+m}^{n}$ is implied from the year-end $n-$ and $m+n-$ year zero-coupon interest rates as follows:

$$
\mathbb{E}_{t} L_{i, t+n}^{m}=\frac{(m+n) L_{i, t}^{m+n}-n L_{i, t}^{n}}{m}
$$

We employ the 5-to-10-year forward real interest as the dependent variable ${ }^{13}$.

\subsubsection{Expected public debt}

We employ projections of gross public debt to-GDP-ratio $\mathbb{E}_{t}$ Debt $_{i, t+n}$ by the IMF World Economic Outlook, Article IV Consultations, OECD Economic Outlook, European Commission (EC) European Economic Forecast, and Economist Intelligence Unit (EIU). Following Gruber and Kamin (2012) and Ichiue and Shimizu (2015), we use two-year-ahead projections of gross public debt-to-GDP-ratio as an independent variable ${ }^{14}$. Since the IMF World Economic Outlook releases its public debt projections for most countries twice a year, we use biannual data. However, as OECD, EC and IMF Article IV Consultations had made two-year-ahead projections once a year over the years, we interpolate the same projections to construct bi-annual data.

\subsubsection{Foreign private holdings ratio}

We use the lagged share of private foreign investors $f p_{i, t-1}$ as the threshold variable and one independent variable. The composition of government bond holdings is drawn from Arslanalp and Tsuda (2014a) and Arslanalp and Tsuda (2014b). As we use forward interest rates for government debt securities denominated in the local currency, the foreign private holdings ratio $f p_{i, t-1}$ is measured as the foreign private holdings share of government debt securities denominated in the local currency ${ }^{15}$.

\footnotetext{
${ }^{13}$ The zero-coupon interest rate can be obtained from Bloomberg. To deflate the nominal interest rate into real interest rate, we use two-year-ahead projections of inflation $\mathbb{E}_{t} \pi_{i, t+2}$ due to data availability. The robustness check examine the nominal interest rate as well.

${ }^{14}$ Moreover, real-time vintages of data could affect long-term interest rates because fiscal data has been revised largely (De Castro et al. (2013)).

${ }^{15}$ While Arslanalp and Tsuda (2014b) provide foreign holdings share of central government debt securities denominated in local currency for emerging markets,Arslanalp and Tsuda (2014a) do not have the corresponding ratio in advanced economies but provides total general government debt securities including both debts denominated in local and foreign currency. Hence, assuming that only foreign investors hold government debt securities denominated in foreign currency (data that can be obtained from the Bank
} 


\subsubsection{Other control variables}

A vector of control variables $\mathbf{z}_{\mathbf{i}, \mathbf{t}}$ includes several variables. First, we use the lagged domestic official sector holdings ratio $d o_{i, t-1}$ as a control variable. Major central banks in advanced economies have been important players in the government bond markets, purchasing government bonds financed by the creation of central bank reserves through quantitative easing — which central banks have implemented to put downward pressure on interest rates when policy rates were at or near zero. The portfolio balance channel operates when the central bank's bond purchases, which change the relative supply of assets held by the private sector, induce equilibrating changes in the relative yields ${ }^{16}$. In the United States, Gagnon et al. (2011) show a cumulative decline in the 10-year Treasury yields by about 91 basis points after announcements of quantitative easing. According to Joyce et al. (2011), the corresponding impacts in the United Kingdom is estimated to be 100 basis points.

Second, we add the lagged foreign official holdings ratio $f o_{i, t-1}$ using data from Arslanalp and Tsuda (2014a) and Arslanalp and Tsuda (2014b). The U.S. long-term interest rates remained low in the mid-2000s despite increases in the federal funds rate, a phenomenon Alan Greenspan labeled a "conundrum" (Greenspan (2005)). Bernanke (2005) hypothesized that a global saving glut - driven by net savings in Asia and oilexporting countries - lowered long-term interest rates through an accumulation of foreign exchange reserves. Warnock and Warnock (2009) show that a 12-month total of foreign flows of one percentage point of GDP is associated with a 40 basis point reduction. Beltran et al. (2013) find that a 10 percentage point increase in foreign official flows into and out of Treasuries lowers the five-year term premium by 135 basis points.

Third, following Gruber and Kamin (2012), we add two-year-ahead projections of real GDP growth rate $\mathbb{E}_{t} y_{i, t+2}$ which can be obtained from Consensus Economics Consensus Forecast, the IMF World Economic Outlook, Article IV Consultations, OECD Economic Outlook, European Commission (EC) European Economic Forecast and the EIU.

Finally, we control for the expected exchange depreciation in a two-year horizon : the rate of change between the two-year-ahead projections of the expected exchange rate and the current year estimation of each

for International Settlements Debt Securities Statistics), we make an approximate estimate of the foreign holdings share of general government debt securities denominated in local currency by removing the amount of debt securities denominated in foreign currency from the total. Finally, we divide the foreign holdings ratio into a foreign private holdings ratio $f p_{i, t-1}$ and a foreign official holdings ratio $f o_{i, t-1}$ using data from Arslanalp and Tsuda (2014a) and Arslanalp and Tsuda (2014b).

${ }^{16}$ Christensen and Rudebusch (2012), D'Amico et al. (2012) and Joyce et al. (2017) provide further discussion. 
currency's exchange rate against the US dollar $\mathbb{E}_{t}$ Exchange rate $_{i, t+2}$, using Consensus Forecast. As foreign investors may be measuring returns in exchange rate adjusted terms, currency depreciation would cause them to demand this risk premium. Ebeke and $\mathrm{Lu}$ (2015) control for the two-year-forward exchange rate of each currency against the US dollar.

\section{Estimation results}

\subsection{Baseline results}

Table 2 shows the baseline results. The tests for nonlinearity are significant with p-values smaller than $0.01^{17}$. Thus, we employ the IT, PSTR and GPSTR models instead of the linear model. This result illustrates that the debt composition plays an important role on the non-linear behavior of the long-term interest rate.

\subsubsection{Marginal impact of the expected public debt}

The main parameters of interest here are $\beta_{0}$ and $\beta_{1}$. As expected, $\beta_{1}$ is larger than $\beta_{0}$ in the IT, PSTR and GPSTR models. These results illustrate that the more the public debt is financed by foreign private investors, the greater is the impact of the increase in the expected public debt on the interest rate. Figure 6 shows the marginal impact of the expected public debt on the interest rate $\left(\frac{\partial \mathbb{E}_{t} L_{i, t+n}}{\partial \mathbb{E}_{t} D e b t_{i, t+n}}\right)$. One striking feature of this chart is that this impact, estimated through the GPSTR model, increases exponentially and significantly as the foreign private holdings ratio exceeds the location parameter while the corresponding impact estimated through the IT model increases constantly and through PSTR model becomes flattened. The right panel of Figure 6 show if the share of foreign investors are 20,30 and 40 percent, the marginal impacts of public debt on the interest rate are 1.7, 3.3 and 5.5 percent points, respectively ${ }^{18}$. The result of the GPSTR model is consistent with DSGE studies, such as Schmitt-Grohe and Uribe (2003), Adolfson et al. (2007), and García-Cicco et al. (2010) that assume an exponential relationship between risk premia and foreign debt.

By contrast, when the foreign private holdings ratios are below about 20 percent, the result of the GPSTR

\footnotetext{
${ }^{17}$ In the linearity test, we follow Luukkonen et al. (1988) and Terasvirta (1994), replacing the transition function $g(\cdot)$ of the PSTR and GPSTR models with the first-order Taylor expansion (Please see Appendix A.1 for details). The conversion gives the IT model. Hence, the tests of the IT, PSTR and GPSTR models for nonlinearity show the same results.

${ }^{18}$ Following Driscoll and Kraay (1998), standard errors are corrected for serial correlation, heteroskedasticity, and cross-sectional dependence.
} 
model illustrates that there is no significant impact of public debt on long-term government bond yields. This implies that domestic investors are insensitive to the expected public debt. In other words, domestic investors may not require a risk premium against large debt when there is strong home bias without any other assets hedging fiscal risk, which is line with Japan’s debt literature (Sakuragawa and Sakuragawa (2016)).

Figure 8 shows the range of the time-varying impact of the expected public debt-to-GDP ratio on the interest rate during $2006 \mathrm{H} 2-2018 \mathrm{H} 2$. As the share of foreign private investors in the small open economy is easily affected by the capital flow, the sovereign risk would be changeable for the short-term. On the other hand, the corresponding impact would be small and stable in large economies or countries with the capital control or higher home bias because the share of foreign private investors remains low. According to the upper panel, the problem about the IT model is that some estimated impacts are negative in countries where the share of private foreign investor is low. This unreasonable result suggests the high non-linear model is appropriate. The middle and upper panels show there is no negative one in the result of PSTR and GPSTR.

\subsubsection{Marginal impact of the share of foreign private investors}

Another parameter of interest here is the coefficient of the lagged share of foreign private investors; $\delta$. According to Table 2, an increase in foreign private holdings of government debt is associated with a reduction in the interest rate, which is consistent with the literature (Arslanalp and Poghosyan (2016) and Ebeke and Lu (2015)), putting downward pressure on long-term interest rates by expanding market liquidity.

Figure 7 shows the marginal impact of the share of foreign investors on the long-term interest rates $\left(\frac{\partial \mathbb{E}_{t} L_{i, t+n}}{\partial f p_{i, t-1}}\right)$ . The left panel of Figure 7 from the result of the IT model shows that this impact varies, depending on the public debt to GDP ratio. The expected public debt-to-GDP ratio $\mathbb{E}_{t}$ Debt $_{i, t+n}$ is estimated to be about 120 percent to GDP ratio when the marginal impact of the share of foreign private investors on the interest rate is zero ${ }^{19}$. That is, although an increase in foreign private holdings of government debt is associated with a reduction in the interest rates, this downward effect would be reversed if the expected public debt-to-GDP ratio exceeds this threshold.

The right panel of Figure 7 from the GPSTR model shows that the marginal impact of the share of foreign investors on the long-term interest rates also depends on the composition of debt, as well as the expected public

\footnotetext{
${ }^{19}$ The threshold can be calculated from $\mathbb{E}_{t}$ Debt $_{i, t+n}=\frac{-\delta}{\beta_{1}}$ in Table 1.
} 
debt. The expected public debt $\mathbb{E}_{t} D e b t_{i, t+n}$ triggers a surge in government bond yields through an increase in the share of foreign investors. Given that the marginal impact of the share of foreign private investors on the interest rate is zero, the threshold of expected public debt is high (low) when the share of foreign investors is low (high). For example, when the share of foreign investors is 15 percent, the threshold of expected public debt is 91 percent. In comparison, when the share of foreign investors is 30 percent, the threshold is 59 percent 20. As the impact of public debt on the interest rate of the GPSTR model continues to increase exponentially depending on the foreign private holdings ratio, an increase in foreign private holdings of government debt would cause a rise in long-term interest rates even the debt level is low. Hence, the result of the GPSTR model differs substantially from those of the IT and PSTR models ${ }^{21}$.

\subsection{Robustness check}

We consider a wide range of exercises to check the robustness of our headline findings with the following specifications: controlling for global and country-specific factors.

\subsubsection{Global factor}

Robustness check 1(controlling for U.S. monetary condition): The baseline might already incorporate global factors because it includes the share of foreign investors. A growing literature also investigates how bond spreads especially in emerging markets are related to global factors, especially the U.S. monetary condition. For example, Mauro et al. (2002) and González-Rozada and Levy Yeyati (2008), using sovereign bonds denominated in U.S. dollars concludes that spreads comove across emerging markets and tend to be most related to global events and global liquidity. Foley-Fisher and Guimaraes (2013) and Gilchrist et al. (2019) also examine spillovers from the changes in U.S. interest rates on sovereign bond yields denominated in foreign currencies. Moreover, Longstaff et al. (2011) find similar evidence based on the sovereign CDS market where the reference obligation is a US dollar-denominated issue or a Euro-dominated issue.

While foreign currency bonds have been widely used by previous works as above, recent literature has

\footnotetext{
${ }^{20}$ The threshold can be calculated from $\mathbb{E}_{t} D_{e b t_{i, t+n}}=\frac{-\delta}{\beta_{1}\left\{\frac{\partial g\left(f p_{i, t-1} ; \gamma_{1}, \gamma_{2}, c\right)}{\partial f p_{i, t-1}}\right\}}$ in Table 1.

${ }^{21}$ As shown in the central panels of Figure 7 for the PSTR model, the marginal impacts of the share of foreign investor on the long-term interest rates over the location parameter are the same because of the assumption of the point symmetry. This result, which it is difficult to interpret is one reason why we develop the GPSTR model to investigate the point asymmetry.
} 
examined the local currency bonds as well. For instance, Moore et al. (2013) analyze the effect of US monetary policy on local currency sovereign yields.

Although the baseline might already incorporate global factors through the share of foreign investors, we control for the U.S. 10-year term premia based on Adrian and Crump (2013), excluding the observation in the United States from the sample ${ }^{22}$.

\subsubsection{Country-specific factors}

Robustness check 2 (excluding exchange rate risk): The baseline includes both the share of foreign investors and the expected exchange depreciation as independent variables. Although we take a lagged value of the share of foreign investor, it may decline due to the expected exchange depreciation if they take the forward-looking behavior. As there may be multicollinearity between these two variables, we exclude the expected exchange depreciation.

Robustness check 3 (controlling for the net foreign assets position): Following Brzoza-Brzezina and Kotlowski (2018), we control for the lagged net foreign assets to GDP ratio $N F A_{i, t-1}$. Reinhart and Trebesch (2015) argue that an increase in the share of foreign investors is associated with lower long-term interest rates because these holdings supplement domestic savings in capital-scarce countries. By contrast, a chronic excess of saving over investments may cause low real interest rates.

Robustness check 4 (controlling for the capital control): Capital control would lower sovereign risk because the regulation of capital flows may possibly prevent crises (Wright (2006)). Fernández et al. (2016) construct the index that represents the existence of capital control for bond inflow and outflow restrictions. Hence, we add this capital control dummy variable $C C_{i, t-1}$ for the additional robustness check.

Robustness check 5 (controlling for the short-term interest rate): We employ forward interest rates to omit any effects of current economic conditions. However, if the current monetary policy affects the forward interest

\footnotetext{
${ }^{22}$ We directly control for the US monetary condition. However, as a manifestation of the investors' risk-taking behavior amid low interest rates of advanced economies, the "search-for-yield" could cause the share of private foreign investors to increase in emerging markets. Moore et al. (2013) show that a 1 percentage point drop in the US 10-year Treasury bond yield leads on average to a 4.2 percentage point increase in foreign holdings of government bonds in emerging markets. Therefore, future research could control the US monetary condition indirectly by using the instrumental variables to deal with the endogeneity of the share of foreign investors without taking a lagged value. However, Yu (2013) find inconsistency in the two-step-least-squares estimators in threshold models when the threshold variable is endogenous. Caner and Hansen (2004) use two step least square estimators in the threshold model where they allow for endogenous regressors, but they assume the threshold variable to be exogenous. Furthermore, Yu (2013) point out that the estimator based on a misspecified reduced form is inconsistent even if the threshold variable is exogenous. Employing instrumental variables is an interesting future topic for research.
} 
rates, omitted variable bias would occurs due to misspecification. Hence, we control for the one-year zero coupon rate $S T R_{i, t}$.

Robustness check $6^{23}$ (dependent variable: nominal interest rates): Ichiue and Shimizu (2015) use the 6-to-10-year-ahead projection of the inflation rate to match the horizon reflected in the 5-to-10-year forward interest rate for 10 advanced economies. However, as our baseline deflates the 5-to-10-year nominal forward rate into real interest rate by two-year-ahead projections of inflation due to data availability, the forecasting horizon of the inflation does not match that of the 5-to-10-year forward nominal interest rate. Hence, the additional robustness check can use the nominal interest rate as the dependent variable and add the two-yearahead projections of inflation to the independent variable.

According to Table 3, 4, 5 and Figure 9, the results for the robustness checks are in line with the baseline results. According to the results for the GPSTR model, the impact of the expected public debt on the interest rate increases exponentially and significantly as the foreign private holdings ratio exceeds the location parameter. For the robustness chcek2, the estimated impact of a 1 percentage point increase in the U.S. 10-year term premium is about 0.5 percentage point. Instead, the marginal impact of the share of foreign investors becomes smaller than the baseline because the US monetary condition affects the behavior of foreign investors. Moreover, the corresponding impact of the public debt is also smaller than the baseline when the share of the private investors is higher. The results of robustness checks 3 and 4 show that both the higher net foreign assets position and capital control lower the interest rates.

\subsection{Model evaluation}

The IT, PSTR, and GPSTR models are competing models because non-linearity tests reject the null hypothesis of the linear model. As argued by Granger (2001), it is well known that nonlinear models are inclined to overfit

\footnotetext{
${ }^{23}$ Additional robustness check considers the expectation for fiscal consolidation so as to avoid sovereign default. This idea is derived from "fiscal limit", i.e., a point where the government no longer has the ability to finance higher debt levels by increasing the tax rate to the revenue-maximizing tax rate (Bi (2012)). The sovereign risk premium is associated with the fiscal limit, assuming the sovereign default occurs when government debt exceeds the fiscal limit. Empirically, Nakamura and Yagi (2017) use the national burden ratio (as a ratio to nominal GDP), that is the sum of tax payments and social security fees, as a variable representing the expectation for fiscal consolidation. They find that a low national burden ratio keeps long-term interest rates at low levels in 23 advanced economies. However, as our sample includes emerging markets, we don not find the similar result. The possible reason is that although the national burden ratio in emerging markets is lower than advanced economies, this does not necessarily illustrate that the government might potentially have the ability to increase the tax revenue because there are many types of obstacles concerning their economic structure (e.g., a large informal sector and dependence on a few natural resources. Please see Besley and Persson (2014) for further details.) .
} 
the data and thus, out-of-sample forecasting evaluation is recommended. Hence, we employ cross-validation to calculate the mean squared error (MSE) .

We start to estimate three models for the new in-sample by leaving out all observations of the $i$ th crosssection. Using estimated parameters, we plug in all observations of the $i$ th cross-section and then calculate the MSE, comparing the estimated fitted values and the actual values as below:

$$
\frac{1}{N T} \hat{e}^{2}=\frac{1}{N T} \sum_{i=1}^{N} \sum_{t=1}^{T}\left[\widetilde{y}_{i, t}-\widehat{\Psi}_{-i}\left(x_{i, t}^{*}\right)\right]^{2}
$$

where $\widehat{\Psi}_{-i}(\cdot)$ is computed by leaving out all observations of the $i$ th cross-section. $\frac{1}{N T} \hat{e}_{I T}^{2} \frac{1}{N T} \hat{e}_{P S T R}^{2}$, and $\frac{1}{N T} \hat{e}_{G P S T R}^{2}$ are MSEs of the IT, PSTR, and GPSTR models, respectively.

Table 6 shows the comparison of MSEs of three models and illustrates that the out-of-sample forecast errors of the GPSTR model are smaller than those of the IT and PSTR models for all cases. This means that the GPSTR model is robust against the sample selection.

\subsection{Comparison with other studies}

Table 7 compares our estimates with those of other studies from three respects: (1) the impact of an increase in expected public debt on government bond yields, (2) the impact of an increase in the share of foreign investors on government bond yield, and (3) the threshold value for the impact of an increase in the share of foreign investors.

First, significant research has been devoted to estimating the positive impact of public debt on long-term interest rates, focusing on government debt securities denominated in local currency. The corresponding impacts in advanced economies are smaller than those in emerging markets(Arslanalp and Poghosyan (2016), Gruber and Kamin (2012), Ichiue and Shimizu (2015) and Jaramillo and Weber (2013)) ${ }^{24}$. Our result shows that the more the public debt is financed by foreign private investors, the greater is the impact of an increase in the expected public debt on the forward interest rate. Overall, the range of our estimated impacts of an increase in public debt on long-term interest rates is consistent with that of existing literature.

Second, our result shows that an increase in foreign private holdings of government debt is also associated

\footnotetext{
${ }^{24}$ As the studies employ different sample periods, they are not necessarily comparable.
} 
with a reduction in long-term interest rates, which is consistent with the literature (Arslanalp and Poghosyan (2016) and Ebeke and Lu (2015)).

Third, Ebeke and Lu (2015) show that in emerging markets an increase in the share of foreign holdings has a negative impact on yield but if either the lagged external debt-to-GDP ratio exceeds 90 percent or the lagged short-term debt-to-GDP ratio exceeds 21.5 percent, the corresponding impacts turn positive. Our corresponding result from the GPSTR model indicates that the threshold of expected public debt is high (low) when the share of foreign investors is low (high). For example, when the share of foreign investors is 15 percent, the threshold of the expected public debt is 91 percent. In comparison, when the share of foreign investors is 30 percent, the threshold is 59 percent. As the marginal impact of the expected public debt on the interest rate using the GPSTR model continues to increase exponentially, depending on the foreign private holdings ratio, an increase in foreign private holdings of government debt would cause a rise in long-term interest rates, even if the debt level is low. Hence, the result of the GPSTR model differs substantially from that of the IT model.

\section{Conclusion}

In summary, this study investigates the threshold values to understand the non-linear behavior of the long-term interest rate by developing a novel approach : a panel smooth transition regression with a general logistic model (i.e., a generalized panel smooth transition regression). We examine how the interaction between the funding source and the expected public debt affects the interest rates in 11 advanced economies and 14 emerging markets using forecast data. Our main findings are threefold:

(i) The impact of the expected public debt on the interest rate would increase exponentially and significantly as the foreign private holdings ratio exceeds approximately 20 percent. Otherwise, strong home bias would mitigate the upward pressure of an increase in public debt on the interest rate.

(ii) If the expected public debt-to-GDP ratio exceeds a certain level that depends on the funding source, an increase in foreign private holding of government debt would cause a rise in long-term interest rates, offsetting the downward effect on long-term interest rates by expanding market liquidity.

(iii) The out-of-sample forecast of the generalized panel smooth transition regression model is more accurate than those of previous other methods: the interaction term and panel smooth transition regression models.

As such, the composition of government debt has a significant impact on the highly non-linear behavior 
of the long-term interest rate. This is an important finding for policy makers with regard to making debt projections, as they need to consider how the government bond yield reacts to the public debt. In particular, as the share of foreign private investors in a small open economy is easily affected by capital flows, the sovereign risk would be changeable for the short-term. From a long-term perspective, Hoshi and Ito (2014) point out that an increase in local-currency-denominated domestic assets would slow down due to the rapid aging of the population in Japan. As the government cannot rely on private domestic investors in some points, the foreign investors would have to step in and absorb the government debt. Consequently, the sovereign risk would be more sensitive than before.

For future research, we could deal with the endogeneity of the share of foreign investors by using instrumental variables. This study took a lagged value of foreign investors to avoid a simultaneity bias and it maintained the assumption of exogeneity. However, it could relax this assumption by allowing for endogenous regressors although that might be econometrically challenging ${ }^{25}$.

\section{References}

Adolfson, M., S. Laseen, J. Linde, and M. Villani. 2007. "Bayesian estimation of an open economy DSGE model with incomplete pass-through.” Journal of International Economics 72:481-511.

Adrian, T., and E. Crump, Richard Moench. 2013. "Pricing the term structure with linear regressions." Journal of Financial Economics 110:110-138.

Agca, S., and O. Celasun. 2012. "Sovereign debt and corporate borrowing costs in emerging markets." Journal of International Economics 88:198-208.

Amstad, M., F. Packer, and J. Shek. 2020. “Does sovereign risk in local and foreign currency differ?” Journal of International Money and Finance 101:1-16.

Arslanalp, S., and T. Poghosyan. 2016. "Foreign Investor Flows and Sovereign Bond Yields in Advanced Economies.” Journal of Banking and Financial Economics 2016:45-67.

\footnotetext{
${ }^{25}$ Please see Section 3.2 for details.
} 
Arslanalp, S., and T. Tsuda. 2014a. “Tracking Global Demand for Advanced Economy Sovereign Debt.” IMF Economic Review 62:430-464.

—. 2014b. "Tracking Global Demand for Emerging Market Sovereign Debt." IMF Working Paper No. 14/39, International Monetary Fund, Washington, DC.

Asonuma, T., S. Bakhache, and H. Hesse. 2015. "Is Banks' Home Bias Good or Bad for Debt Sustainability?" IMF Working Paper No. 15/44, International Monetary Fund, Washington, DC.

Azzimonti, M., E. de Francisco, and V. Quadrini. 2014. "Financial Globalization, Inequality, and the Rising Public Debt.” American Economic Review 104:2267-2302.

Azzimonti, M., and V. Quadrini. 2017. “The Politics of Sovereign Default under Financial Integration.”, Unpublished manuscript.

Beltran, D.O., M. Kretchmer, J. Marquez, and C.P. Thomas. 2013. "Foreign holdings of U.S. Treasuries and U.S. Treasury yields.” Journal of International Money and Finance 32:1120-1143.

Bernanke, B.S. 2005. "The global saving glut and the U.S. current account deficit." Speech 77, Board of Governors of the Federal Reserve System (U.S.).

Besley, T., and T. Persson. 2014. "Why Do Developing Countries Tax So Little?” Journal of Economic Perspectives 28(4):99-120.

Bi, H. 2012. "Sovereign default risk premia, fiscal limits, and fiscal policy." European Economic Review 56:389-410.

Bonner, C. 2016. "Preferential Regulatory Treatment and Banks’ Demand for Government Bonds.” Journal of Money, Credit and Banking 48:1195-1221.

Brainard, L. 2017. "Monetary Policy in a Time of Uncertainty : a speech at the Brookings Institution, Washington, D.C., January 17, 2017.” Speech 933, Board of Governors of the Federal Reserve System (U.S.).

Broner, F., A. Erce, A. Martin, and J. Ventura. 2014. "Sovereign debt markets in turbulent times: Creditor discrimination and crowding-out effects.” Journal of Monetary Economics 61:114-142. 
Broner, F., A. Martin, and J. Ventura. 2010. “Sovereign Risk and Secondary Markets.” American Economic Review 100:1523-1555.

Brzoza-Brzezina, M., and J. Kotlowski. 2018. "The nonlinear nature of country risk and its implications for DSGE models." Macroeconomic Dynamics, pp. 1-28.

Caner, M., and B.E. Hansen. 2004. "Instrumental Variable Estimation of a Threshold Model." Econometric Theory 20:813-843.

Carvalho, D., and M. Fidora. 2015. "Capital inflows and euro area long-term interest rates.” Journal of International Money and Finance 54:186-204.

Christensen, J.H.E., and G.D. Rudebusch. 2012. “The Response of Interest Rates to US and UK Quantitative Easing." The Economic Journal 122:385-414.

Colletaz, G., and C. Hurlin. 2006. “Threshold Effects of the Public Capital Productivity : An International Panel Smooth Transition Approach.” LEO Working Papers/DR LEO 1669, Orleans Economics Laboratory, University of Orleans, Orleans.

Cunliffe, J. 2019. "Financial stability post Brexit: risks from global debt, a speech at CFO Agenda, London, May 7, 2019.” Speech, Bank of England.

D’Amico, S., W. English, D. López-Salido, and E. Nelson. 2012. “The Federal Reserve's Large-scale Asset Purchase Programmes: Rationale and Effects.” The Economic Journal 122:415-446.

De Castro, F., J.J. Pérez, and M. Rodríguez-Vives. 2013. "Fiscal Data Revisions in Europe.” Journal of Money, Credit and Banking 45:1187-1209.

Dell'Erba, S., R. Hausmann, and U. Panizza. 2013. "Debt levels, debt composition, and sovereign spreads in emerging and advanced economies." Oxford Review of Economic Policy 29:518-547.

Driscoll, J.C., and A.C. Kraay. 1998. "Consistent Covariance Matrix Estimation with Spatially Dependent Panel Data." The Review of Economics and Statistics 80:549-560.

Ebeke, C., and Y. Lu. 2015. "Emerging market local currency bond yields and foreign holdings -A fortune or misfortune?” Journal of International Money and Finance 59:203-219. 
Engen, E.M., and R.G. Hubbard. 2005. “Federal Government Debt and Interest Rates.” NBER Macroeconomics Annual 2004 19:83-138.

Erce, A., and E. Mallucci. 2018. "Selective Sovereign Defaults.” International Finance Discussion Papers 1239, Board of Governors of the Federal Reserve System.

Fernández, M., Andrésand Klein, A. Rebucci, M. Schindler, and M. Uribe. 2016. "Capital Control Measures: A New Dataset." IMF Economic Review 64:548-574.

Fok, D., D. Van Dijk, and P.H. Franses. 2005. “A multi-level panel STAR model for US manufacturing sectors.” Journal of Applied Econometrics 20:811-827.

Foley-Fisher, N., and B. Guimaraes. 2013. "U.S. Real Interest Rates and Default Risk in Emerging Economies." Journal of Money, Credit and Banking 45:967-975.

Fouquau, J., C. Hurlin, and I. Rabaud. 2008. “The Feldstein-Horioka puzzle: A panel smooth transition regression approach.” Economic Modelling 25:284-299.

Gagnon, J., M. Raskin, J. Remache, and B. Sack. 2011. “The Financial Market Effects of the Federal Reserve's Large-Scale Asset Purchases.” International Journal of Central Banking 7:3-43.

García-Cicco, J., R. Pancrazi, and M. Uribe. 2010. “Real Business Cycles in Emerging Countries?” American Economic Review 100:2510-31.

Gilchrist, S., V. Yue, and E. Zakrajsek. 2019. "US Monetary Policy and International Bond Markets.” Journal of Money, Credit and Banking 51:127-161.

González, A., and T. Teräsvirta. 2006. "Simulation-based Finite Sample Linearity Test against Smooth Transition Models." Oxford Bulletin of Economics and Statistics 68:797-812.

González, A., T. Teräsvirta, D. van Dijk, and Y. Yang. 2017. "Panel Smooth Transition Regression Models." SSE/EFI Working Paper Series in Economics and Finance No 604, Stockholm School of Economics, Stockholm.

González-Rozada, M., and E. Levy Yeyati. 2008. “Global Factors and Emerging Market Spreads.” The Economic Journal 118:917-1936. 
Granger, C.W.J. 2001. “Overview of nonlinear macroeconometric empirical models.” Macroeconomic Dynamics 5:466-481.

Greenspan, A. 2005. "Federal Reserve Board's semiannual monetary policy report to the Congress: testimony before the Committee on Banking, Housing, and Urban Affairs, U.S. Senate, February 16, 2005.” Speech 59, Board of Governors of the Federal Reserve System (U.S.).

Gros, D. 2013. "Foreign debt versus domestic debt in the euro area." Oxford Review of Economic Policy 29:502517.

Gruber, J.W., and S.B. Kamin. 2012. "Fiscal Positions and Government Bond Yields in OECD Countries." Journal of Money, Credit and Banking 44:1563-1587.

Hansen, B.E. 1996. "Inference When a Nuisance Parameter Is Not Identified Under the Null Hypothesis." Econometrica 64:413-430.

—. 1999. "Threshold effects in non-dynamic panels: Estimation, testing and inference." Journal of Econometrics $93: 345-368$.

Hoshi, T., and T. Ito. 2014. "Defying gravity: can Japanese sovereign debt continue to increase without a crisis?" Economic Policy 29:5-44.

Ichiue, H., and Y. Shimizu. 2015. "Determinants of long-term yields: A panel data analysis of major countries." Japan and the World Economy 34-35:44-55.

Jaramillo, L., and A. Weber. 2013. "Bond yields in emerging economies: It matters what state you are in." Emerging Markets Review 17:169-185.

Joyce, M.A., A. Lasaosa, I. Stevens, and M. Tong. 2011. "The Financial Market Impact of Quantitative Easing in the United Kingdom.” International Journal of Central Banking 7:113-161.

Joyce, M.A., Z. Liu, and I. Tonks. 2017. “Institutional Investors and the QE Portfolio Balance Channel.” Journal of Money, Credit and Banking 49:1225-1246.

Lagarias, J.C., J.A. Reeds, M.H. Wright, and P.E. Wright. 1998. "Convergence Properties of the Nelder-Mead Simplex Method in Low Dimensions.” SIAM Journal on Optimization 9:112-147. 
Laubach, T. 2009. "New Evidence on the Interest Rate Effects of Budget Deficits and Debt." Journal of the European Economic Association 7:858-885.

Longstaff, F., J. Pan, L. Pedersen, and K. Singleton. 2011. “How Sovereign Is Sovereign Credit Risk?” American Economic Journal: Macroeconomics 3:75-103.

Luukkonen, R., P. Saikkonen, and T. Terasvirta. 1988. “Testing Linearity Against Smooth Transition Autoregressive Models.” Biometrika 75:491-499.

Mauro, P., N. Sussman, and Y. Yafeh. 2002. "Emerging Market spreads:Then versus now." The Quarterly Journal of Economics 117:695-733.

Miranda, M.J., and P.L. Fackler. 2002. Applied computational economics and finance. MIT Press.

Moore, J., S. Nam, M. Suh, and A. Tepper. 2013. "Estimating the Impacts of the U.S. LSAPs on Emerging Market Economies’ Local Currency Bond Markets.” Federal Reserve Bank of New York Staff Reports 595, Federal Reserve Bank of New York.

Nakamura, K., and T. Yagi. 2017. "Fiscal Conditions and Long-term Interest Rates.” Monetary and Economic Studies,Institute for Monetary and Economic Studies,Bank of Japan 35:59-88.

Ongena, S., A. Popov, and N. Van Horen. 2019. "The Invisible Hand of the Government: Moral Suasion during the European Sovereign Debt Crisis.” American Economic Journal: Macroeconomics 4:346-379.

Ottonello, P., and D. Perez. 2019. “The Currency Composition of Sovereign Debt.” American Economic Journal: Macroeconomics 11:174-208.

Peiris, S.J. 2013. "Foreign Participation in Local Currency Bond Markets of Emerging Economies.” Journal of International Commerce, Economics and Policy 04:1-15.

Reinhart, C.M., K. Rogoff, and M. Savastano. 2003. “Debt Intolerance.” Brookings Papers on Economic Activity 34:1-74.

Reinhart, C.M., and C. Trebesch. 2015. “The pitfalls of external dependence: Greece, 1829-2015.” Brookings Papers on Economic Activity 46:307-328. 
Sakuragawa, M., and Y. Sakuragawa. 2016. “Absence of safe assets and fiscal crisis.” Journal of the Japanese and International Economies 40:59-76.

Schmitt-Grohe, S., and M. Uribe. 2003. "Closing small open economy models." Journal of International Economies 61:163-185.

Shiller, R.J., J.Y. Campbell, and K.L. Schoenholtz. 1983. "Forward Rates and Future Policy: Interpreting the Term Structure of Interest Rates.” Brookings Papers on Economic Activity 14:173-224.

Stukel, T.A. 1988. “Generalized Logistic Models.” Journal of the American Statistical Association 83:426-431.

Sturzenegger, F., and J. Zettelmeyer. 2008. "Haircuts:Estimating investor losses in sovereign debt restructurings,1998-2005.” Journal of International Money and Finance 27:780-805.

Tenreyro, S. 2019. "Monetary policy and open questions in international macroeconomics, a speech at at the John Flemming Memorial Lecture, London, October 28, 2019.” Speech, Bank of England.

Terasvirta, T. 1994. "Specification, Estimation, and Evaluation of Smooth Transition Autoregressive Models." Journal of the American Statistical Association 89:208-288.

Traum, N., and S.C.S. Yang. 2015. “When Does Government Debt Crowd Out Investment?” Journal of Applied Econometrics 30:24-45.

Warnock, F.E., and V.C. Warnock. 2009. "International Capital Flows and U.S. Interest Rates.” Journal of International Money and Finance 28:903-919.

Wright, J.H. 2011. “Term Premia and Inflation Uncertainty: Empirical Evidence from an International Panel Dataset." American Economic Review 101:1514-1534.

Wright, M. 2006. "Private capital flows, capital controls, and default risk." Journal of International Economics 69:120-149.

Yu, P. 2013. "Inconsistency of 2SLS estimators in threshold regression with endogeneity." Economics Letters 120:532-536. 
Figure 1: 5-to-10 year forward interest rates of government debt securities denominated in local currency
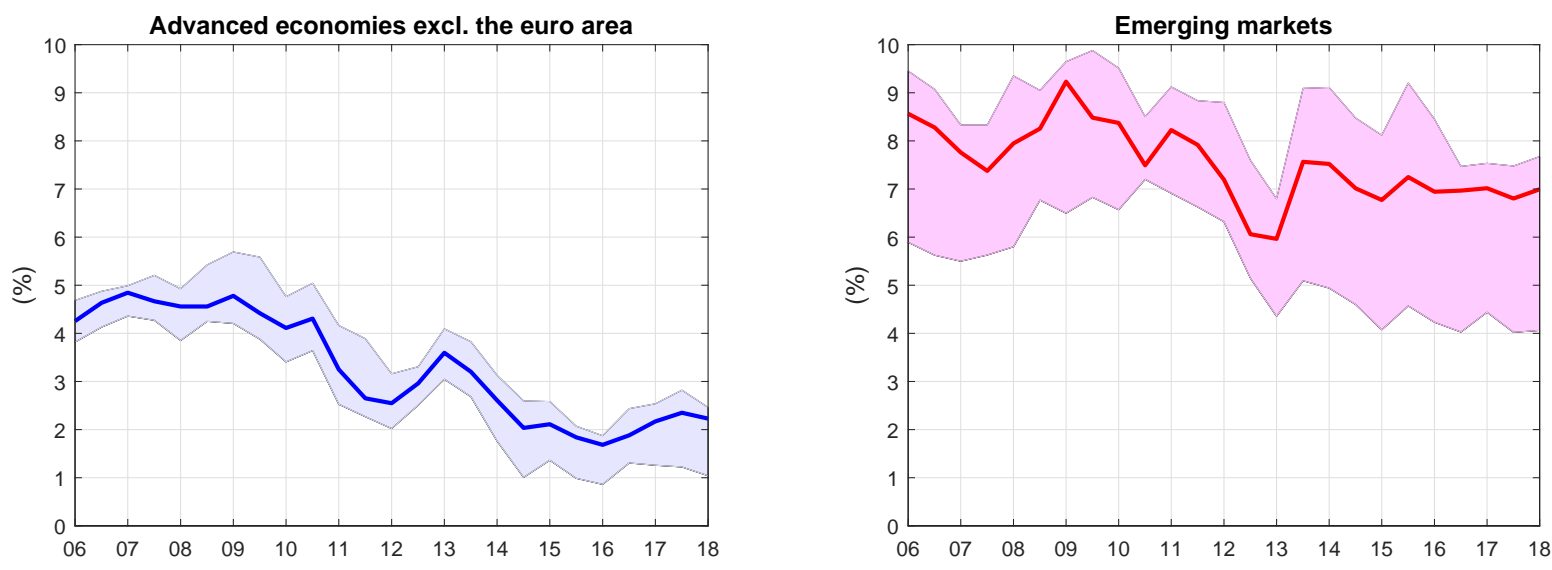

Figure 2: two-year-ahead expected public debt to GDP ratio
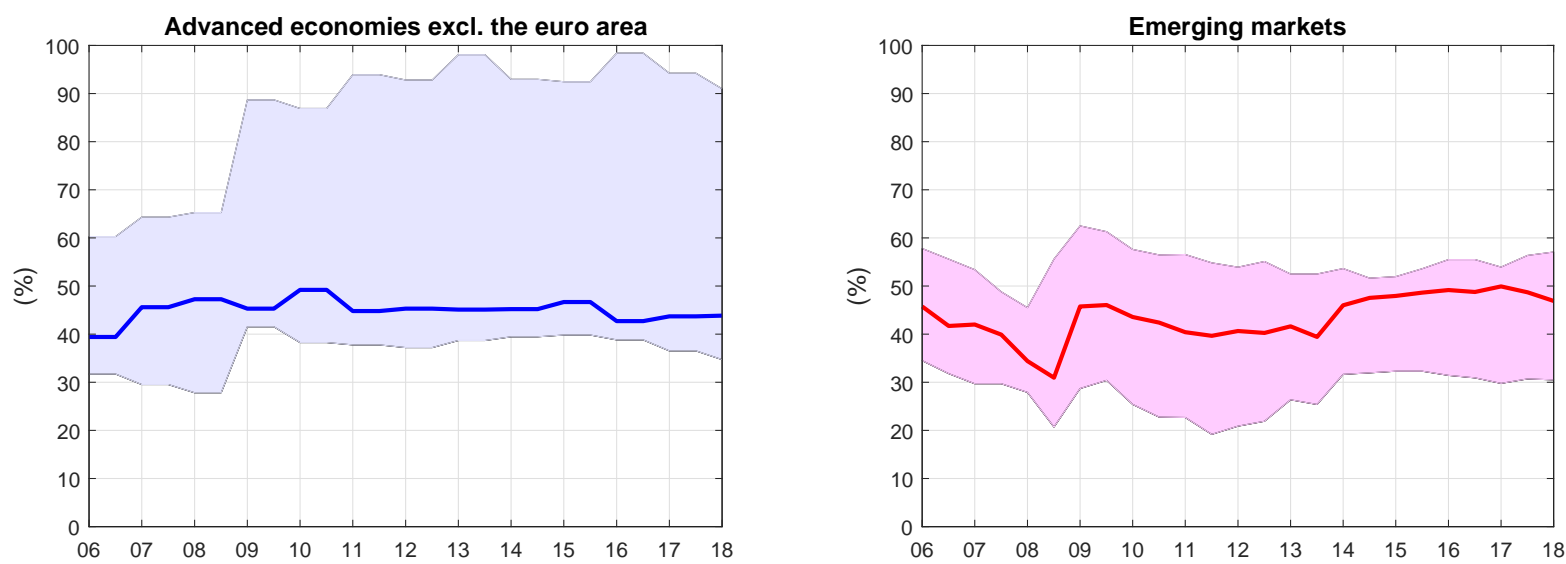

Figure 3: The share of government debt securities denominated in local currency
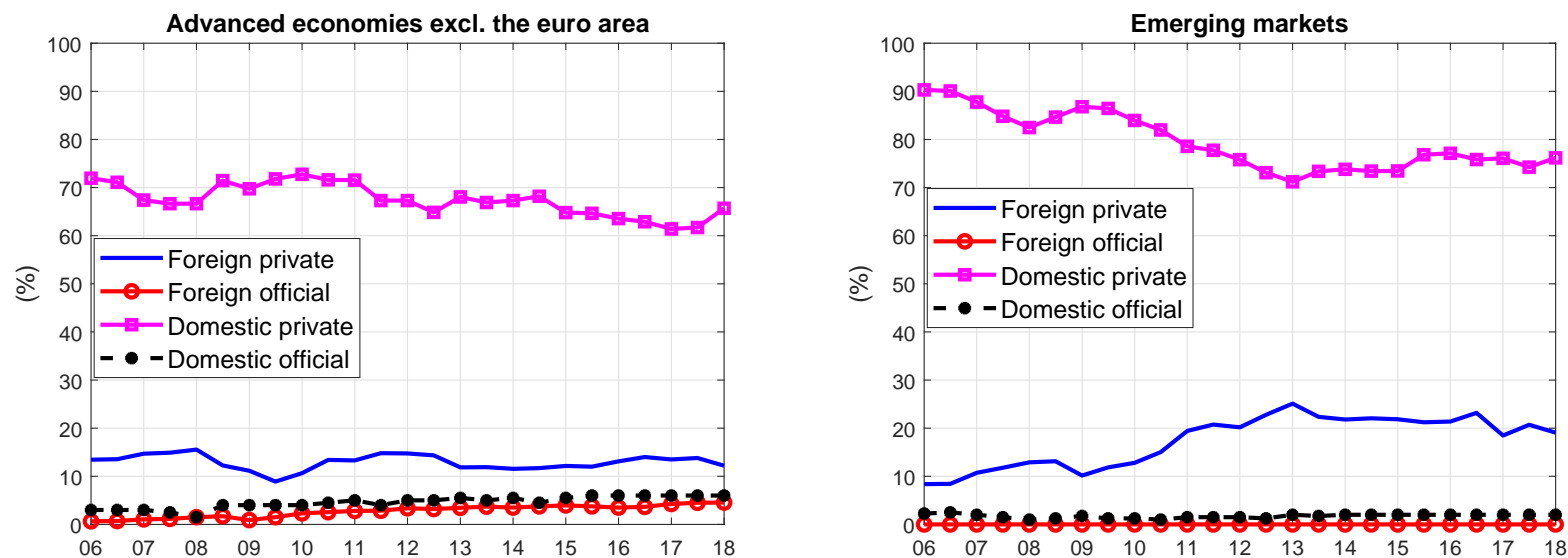

Notes: Advanced economies excluding the euro area(Australia, Canada, the Czech Republic, Denmark, Japan, Korea, Norway, Sweden, Switzerland, the United Kingdom and United States) and emerging markets(Bulgaria, Columbia, China, Hungary, India, Indonesia, Malaysia, Mexico, Peru, the Philippines, Poland, Thailand, Turkey and South Africa). Lines and shadow areas show the median and interquartile range within each country group, respectively. Calculations of share of governmet debt based on data from Arslanalp and Tsuda (2014a), Arslanalp and Tsuda (2014b) and BIS Debt Securities Statistics (See 2.4 Data for details). 
Figure 4: Examples of interaction term and standard logistic model

Interaction term

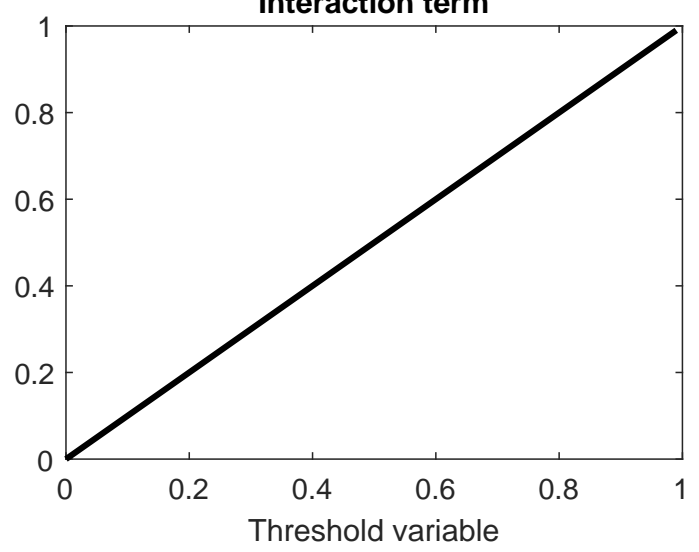

Standard logistic model

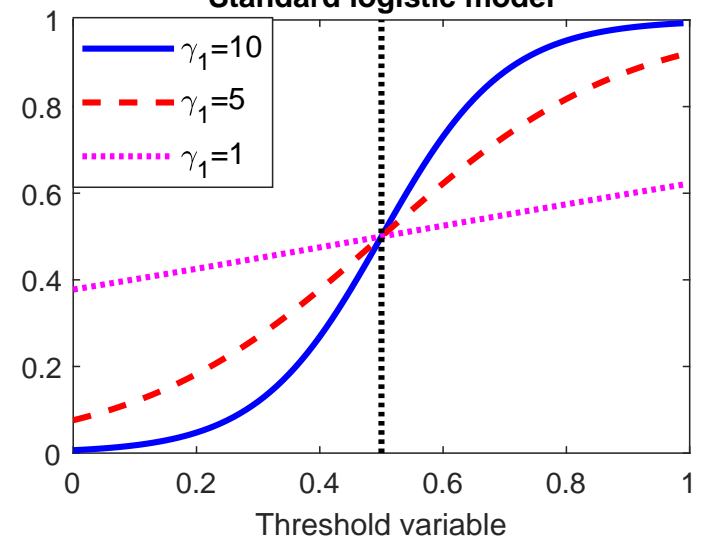

Figure 5: Example of general logistic model (GLM)
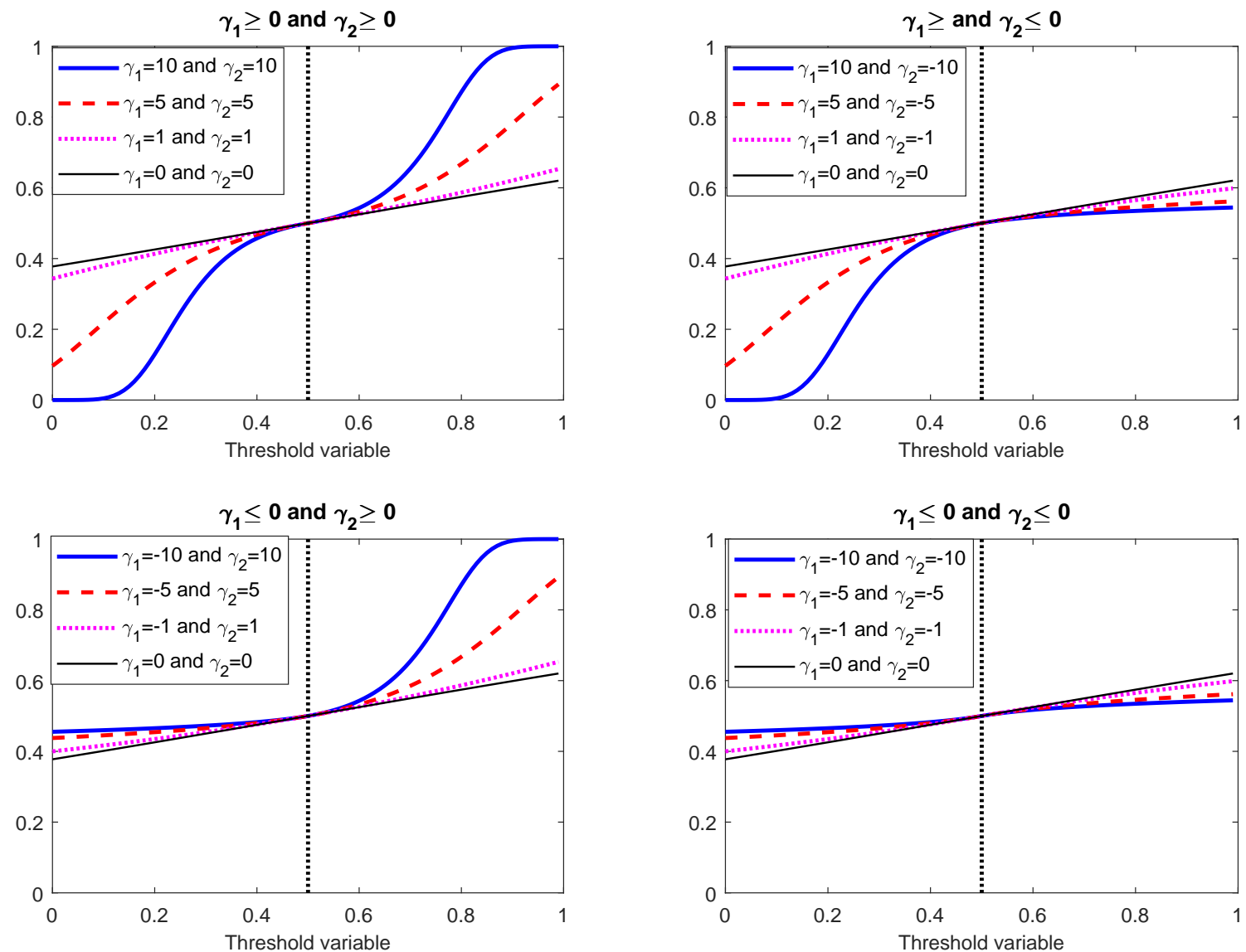

Notes: The location parameter $c=0.5$. 
Table 2: Baseline results

\begin{tabular}{|c|c|c|c|}
\hline Model & IT & PSTR & GPSTR \\
\hline$L M_{F}$ nonlinearity tests & 10.5 & 10.5 & 10.5 \\
\hline $\mathrm{p}$-value & $0.00 * * *$ & $0.00 * * *$ & $0.00 * * *$ \\
\hline Location parameter $(c)$ & & 0.288 & 0.092 \\
\hline Slope parameter $1\left(\gamma_{1}\right)$ & & 15.3 & -64.0 \\
\hline Slope parameter $2\left(\gamma_{2}\right)$ & & & 3.0 \\
\hline \multirow[t]{2}{*}{$\mathbb{E}_{t}$ Debt $_{i, t+2}$} & -0.008 & 0.000 & $-0.196 * * *$ \\
\hline & $(0.01)$ & $(0.01)$ & $(0.01)$ \\
\hline $\mathbb{E}_{t}$ Debt $_{i, t+2} \cdot f p_{t-1}$ & $\begin{array}{c}0.120 * * * \\
(0.04)\end{array}$ & & \\
\hline \multirow[t]{2}{*}{$\mathbb{E}_{t} D_{e b t_{i, t+2} \cdot g(\cdot)}$} & & $0.051 *$ & $0.402 * * *$ \\
\hline & & $(0.03)$ & $(0.03)$ \\
\hline \multirow[t]{2}{*}{$\mathbb{E}_{t} y_{i, t+2}$} & -0.008 & 0.000 & 0.042 \\
\hline & $(0.13)$ & $(0.11)$ & $(0.13)$ \\
\hline \multirow[t]{2}{*}{$d o_{i, t-1}$} & $-0.099 * * *$ & $-0.085 * * *$ & $-0.089 * * *$ \\
\hline & $(0.01)$ & $(0.01)$ & $(0.01)$ \\
\hline \multirow[t]{2}{*}{$f o_{i, t-1}$} & $-0.146 * * *$ & $-0.148 * * *$ & $-0.153 * * *$ \\
\hline & $(0.02)$ & $(0.02)$ & $(0.02)$ \\
\hline \multirow[t]{2}{*}{$f p_{i, t-1}$} & $-0.104 * * *$ & $-0.105 * * *$ & $-0.104 * * *$ \\
\hline & $(0.03)$ & $(0.02)$ & $(0.01)$ \\
\hline \multirow[t]{2}{*}{$\mathbb{E}_{t}$ Exchange rate $_{i, t+2}$} & $0.042 * * *$ & $0.043 * * *$ & $0.041 * * *$ \\
\hline & $(0.01)$ & $(0.01)$ & $(0.01)$ \\
\hline AIC Criterion & -8.563 & -8.562 & -8.573 \\
\hline No. of observation & 625 & 625 & 625 \\
\hline No. of countries & 25 & 25 & 25 \\
\hline Sample periods & $06: 2-18: 2$ & $06: 2-18: 2$ & $06: 2-18: 2$ \\
\hline
\end{tabular}

Notes: IT=Interaction term model,PSTR=Panel Smooth Transition Regression and GPSTR=General Panel Smooth Transition Regression. $\mathbb{E}_{t}$ Debt $_{i, t+2}$ is two-year-ahead expected public debt to GDP ratio, $g(\cdot)$ is transition function, $\mathbb{E}_{t} y_{i, t+2}$ is two-year-ahead expected growth rate, $d o_{i, t-1}$ is the lagged domestic official sector holdings ratio, $f o_{i, t-1}$ the lagged foreign official sector holdings ratio, $f p_{i, t-1}$ is the lagged foreign private sector holdings ratio and $\mathbb{E}_{t} E x c h a n g e$ rat $e_{i, t+2}$ is the expected exchange rate depreciation in two-year horizon. The standard errors proposed by Driscoll and Kraay (1998) are reported in parentheses. ${ }^{* * *} \mathrm{p}<0.01,{ }^{*} \mathrm{p}<0.05$, ${ }^{*} \mathrm{p}<0.1$. 
Figure 6: Marginal impact of the expected public debt-to-GDP ratio on the interest rate (Baseline)
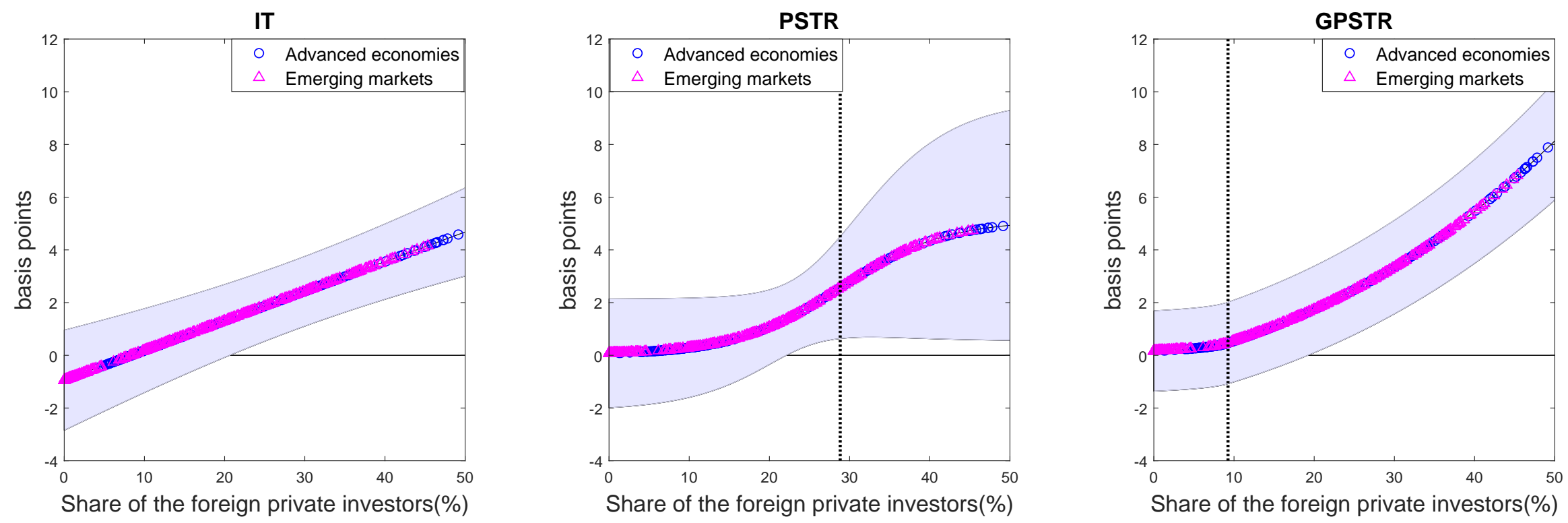

Notes: Shadow area refers to 90 percent confidence interval computed with Driscoll and Kraay (1998) standard errors. Circles and triangles correspond to observation for private foreign share. Broken lines represent location parameters.

Figure 7: Marginal impact of the share of foreign private investors on the interest rate (Baseline)

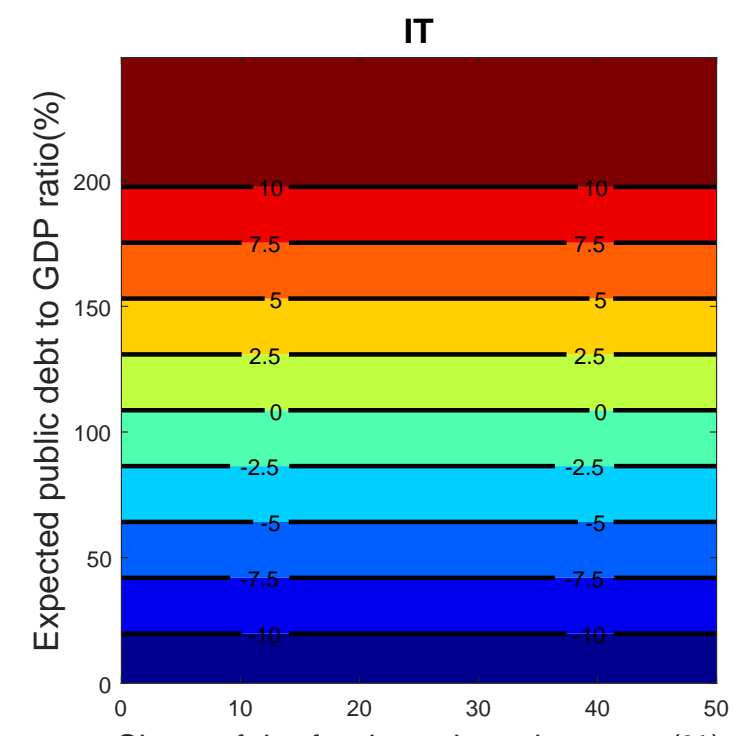

Share of the foreign private investors(\%)

Notes: Basis points.
PSTR

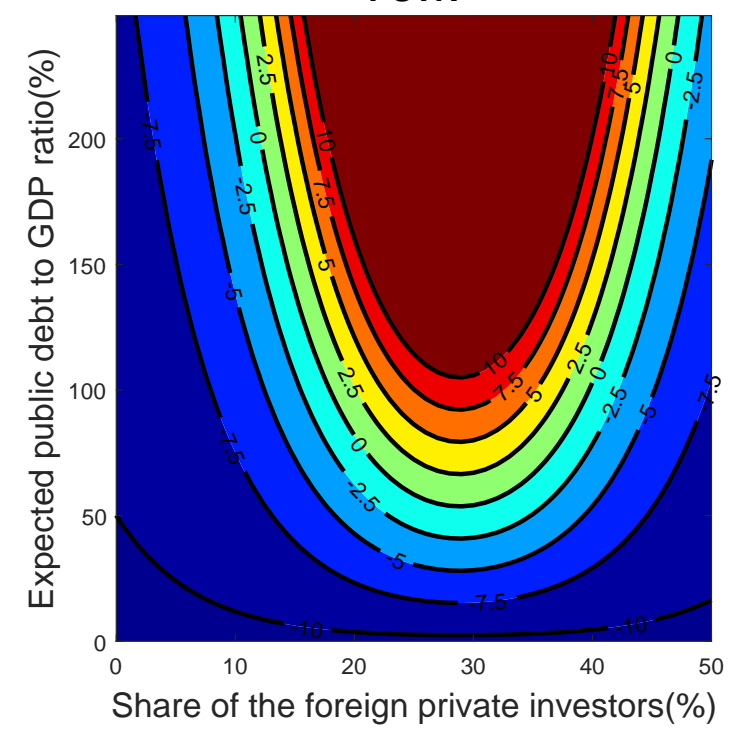

GPSTR

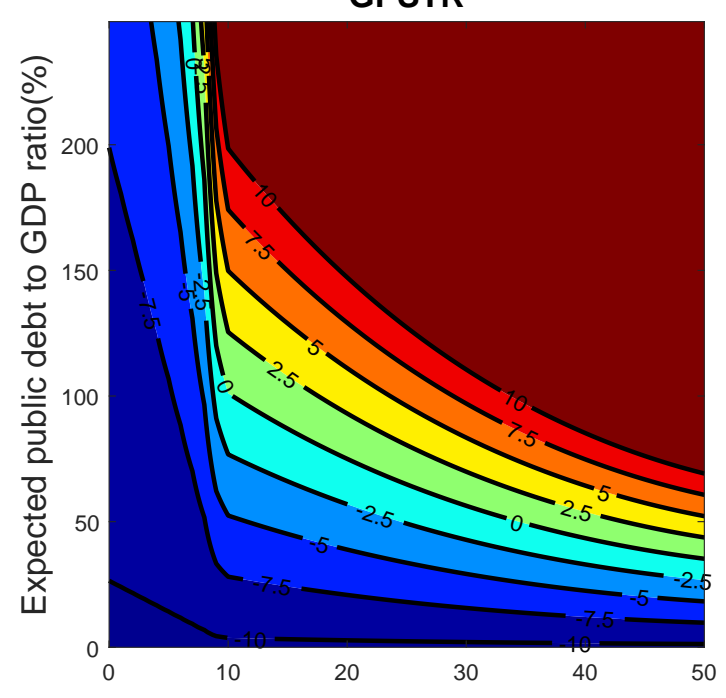

Share of the foreign private investors(\%) 
Figure 8: Range of the time-varying impact of the expected public debt-to-GDP ratio on the interest rate during 2006H2-2018H2 (Baseline)
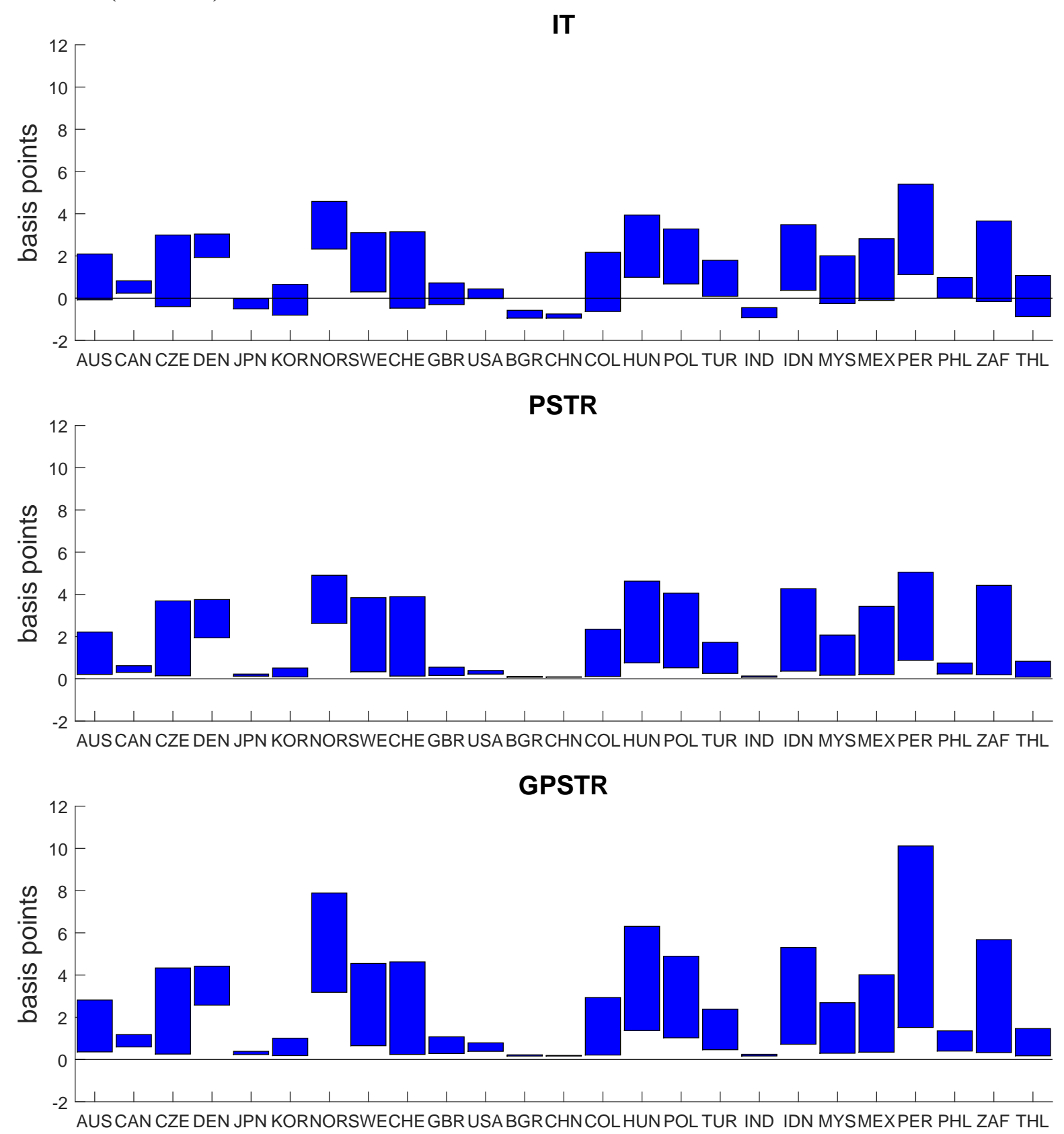

Notes: The range is the difference between the maximum and minimum point estimate during 2006H2-2018H2. AUS:Australia, CAN:Canada, CZE:the Czech Republic, DEN:Denmark, JPN:Japan, KOR:Korea, NOR:Norway, SWE:Sweden, CHE:Switzerland, GBR:the United Kingdom, USA:the United States, BGR:Bulgaria, CHN:China,COL:Columbia, HUN:Hungary, POL:Poland, TUR:Turkey, IND:India,IDN:Indonesia, MYS: Malaysia, MEX:Mexico, PER:Peru, PHL:the Philippines, ZAF:South Africa, THL:Thailand 
Table 3: Robustness check 1 and 2

\begin{tabular}{|c|c|c|c|c|c|c|}
\hline & ב- & $\overline{~(\mathrm{R} 1)}$ & 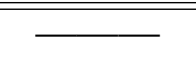 & 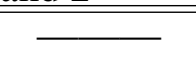 & (R2) & - \\
\hline & IT & PSTR & GPSTR & IT & PSTR & GPSTR \\
\hline$L M_{F}$ nonlinearity test & 9.4 & 9.4 & 9.4 & 11.6 & 11.6 & 11.6 \\
\hline $\mathrm{p}$-value & $0.00 * * *$ & $0.00 * * *$ & $0.00 * * *$ & $0.00 * * *$ & $0.00 * * *$ & $0.00 * * *$ \\
\hline Location parameter $(c)$ & & 0.295 & 0.069 & & 0.293 & 0.092 \\
\hline Slope parameter $1\left(\gamma_{1}\right)$ & & 14.3 & -56.6 & & 14.2 & -51.1 \\
\hline Slope parameter $2\left(\gamma_{2}\right)$ & & & 0.03 & & & 3.1 \\
\hline $\mathbb{E}_{t}$ Debt $_{i, t+2}$ & $\begin{array}{l}-0.008 \\
(0.01)\end{array}$ & $\begin{array}{l}-0.001 \\
(0.01)\end{array}$ & $\begin{array}{l}-0.282 \\
(0.01)\end{array}$ & $\begin{array}{l}-0.007 \\
(0.01)\end{array}$ & $\begin{array}{l}0.000 \\
(0.01)\end{array}$ & $\begin{array}{c}-0.220 * * * \\
(0.01)\end{array}$ \\
\hline $\mathbb{E}_{t} D_{e} b t_{i, t+2} \cdot f p_{t-1}$ & $\begin{array}{c}0.110 * * * \\
(0.03)\end{array}$ & & & $\begin{array}{c}0.127 * * * \\
(0.04)\end{array}$ & & \\
\hline $\mathbb{E}_{t} D_{e b t_{i, t+2}} \cdot g(\cdot)$ & & $\begin{array}{c}0.049 * * \\
(0.02)\end{array}$ & $\begin{array}{c}0.557 * * * \\
(0.03)\end{array}$ & & $\begin{array}{l}0.056 \\
(0.04)\end{array}$ & $\begin{array}{c}0.450 * * * \\
(0.03)\end{array}$ \\
\hline $\mathbb{E}_{t} y_{i, t+2}$ & $\begin{array}{l}-0.117 \\
(0.15)\end{array}$ & $\begin{array}{l}-0.111 \\
(0.15)\end{array}$ & $\begin{array}{l}-0.083 \\
(0.14)\end{array}$ & $\begin{array}{l}0.011 \\
(0.13)\end{array}$ & $\begin{array}{l}0.020 \\
(0.13)\end{array}$ & $\begin{array}{l}0.063 \\
(0.13)\end{array}$ \\
\hline$d o_{i, t-1}$ & $\begin{array}{c}-0.067 * * * \\
(0.02)\end{array}$ & $\begin{array}{c}-0.054 * * * \\
(0.01)\end{array}$ & $\begin{array}{c}-0.057 * * * \\
(0.02)\end{array}$ & $\begin{array}{c}-0.111 * * * \\
(0.01)\end{array}$ & $\begin{array}{c}-0.097 * * * \\
(0.01)\end{array}$ & $\begin{array}{c}-0.098 * * * \\
(0.01)\end{array}$ \\
\hline$f o_{i, t-1}$ & $\begin{array}{c}-0.098 * * * \\
(0.03)\end{array}$ & $\begin{array}{c}-0.100 * * * \\
(0.02)\end{array}$ & $\begin{array}{c}-0.093 * * * \\
(0.03)\end{array}$ & $\begin{array}{c}-0.153 * * * \\
(0.02)\end{array}$ & $\begin{array}{c}-0.154 * * * \\
(0.02)\end{array}$ & $\begin{array}{c}-0.159 * * * \\
(0.02)\end{array}$ \\
\hline$f p_{i, t-1}$ & $\begin{array}{c}-0.080 * * * \\
(0.02)\end{array}$ & $\begin{array}{c}-0.081 * * * \\
(0.02)\end{array}$ & $\begin{array}{c}-0.082 * * * \\
(0.02)\end{array}$ & $\begin{array}{c}-0.115 * * * \\
(0.02)\end{array}$ & $\begin{array}{c}-0.115 * * * \\
(0.03)\end{array}$ & $\begin{array}{c}-0.118 * * * \\
(0.02)\end{array}$ \\
\hline $\mathbb{E}_{t} E R_{i, t+2}$ & $\begin{array}{c}0.039 * * * \\
(0.01)\end{array}$ & $\begin{array}{c}0.039 * * * \\
(0.01)\end{array}$ & $\begin{array}{c}0.036 * * * \\
(0.01)\end{array}$ & & & \\
\hline$U S t p_{t-1}$ & $\begin{array}{c}0.542 * * * \\
(0.14)\end{array}$ & $\begin{array}{c}0.543 * * * \\
(0.11)\end{array}$ & $\begin{array}{c}0.540 * * * \\
(0.13)\end{array}$ & & & \\
\hline AIC Criterion & -8.636 & -8.636 & -8.640 & -8.547 & -8.545 & -8.559 \\
\hline No. of observation & 600 & 600 & 600 & 625 & 625 & 625 \\
\hline No. of countries & 24 & 24 & 24 & 25 & 25 & 25 \\
\hline Sample periods & $06: 2-18: 2$ & $06: 2-18: 2$ & $06: 2-18: 2$ & $06: 2-18: 2$ & $06: 2-18: 2$ & $06: 2-18: 2$ \\
\hline
\end{tabular}

Notes: IT=Interaction term model,PSTR=Panel Smooth Transition Regression and GPSTR=General Panel Smooth Transition Regression. The sample of (R1) excludes the U.S. $\mathbb{E}_{t}$ Debt $_{i, t+2}$ is two-year-ahead expected public debt to GDP ratio, $g(\cdot)$ is transition function, $\mathbb{E}_{t} y_{i, t+2}$ is two-year-ahead expected growth rate, $d o_{i, t-1}$ is the lagged domestic official sector holdings ratio, $f o_{i, t-1}$ the lagged foreign official sector holdings ratio, $f p_{i, t-1}$ is the lagged foreign private sector holdings ratio, $\mathbb{E}_{t}$ Exchange $_{\text {ate }}$ ent $t+2$ is the expected exchange rate depreciation in two- year horizon and $U S t p_{t-1}$ is the lagged U.S. 10-year term premia. The standard errors proposed by Driscoll and Kraay (1998) are reported in parentheses. ${ }^{* * *} \mathrm{p}<0.01,{ }^{*} \mathrm{p}<0.05,{ }^{*} \mathrm{p}<0.1$ 
Table 4: (Continued) Robustness check 3 and 4

\begin{tabular}{|c|c|c|c|c|c|c|}
\hline & $\longrightarrow$ & (R3) & $\longrightarrow$ & $\longrightarrow$ & (R4) & $\longrightarrow$ \\
\hline & IT & PSTR & GPSTR & IT & PSTR & GPSTR \\
\hline$L M_{F}$ nonlinearity test & 7.0 & 7.0 & 7.0 & 10.0 & 10.0 & 10.0 \\
\hline $\mathrm{p}$-value & $0.01 * * *$ & $0.01 * * *$ & $0.01 * * *$ & $0.00 * * *$ & $0.00 * * *$ & $0.00 * * *$ \\
\hline Location parameter $(c)$ & & 0.335 & 0.092 & & 0.264 & 0.103 \\
\hline Slope parameter $1\left(\gamma_{1}\right)$ & & 15.0 & -35.8 & & 16.2 & -74.8 \\
\hline Slope parameter $2\left(\gamma_{2}\right)$ & & & 4.0 & & & 0.3 \\
\hline $\mathbb{E}_{t} D e b t_{i, t+2}$ & $\begin{array}{l}-0.006 \\
(0.01)\end{array}$ & $\begin{array}{l}0.002 \\
(0.01)\end{array}$ & $\begin{array}{c}-0.162 * * * \\
(0.03)\end{array}$ & $\begin{array}{l}-0.011 \\
(0.01)\end{array}$ & $\begin{array}{c}-0.004 \\
(0.01)\end{array}$ & $\begin{array}{c}-0.321 * * * \\
(0.05)\end{array}$ \\
\hline $\mathbb{E}_{t}$ Debt $_{i, t+2} \cdot f p_{t-1}$ & $\begin{array}{c}0.099 * * * \\
(0.03)\end{array}$ & & & $\begin{array}{c}0.119 * * * \\
(0.03)\end{array}$ & & \\
\hline $\mathbb{E}_{t} D_{e b t_{i, t+2}} \cdot g(\cdot)$ & & $\begin{array}{c}0.050^{*} \\
(0.03)\end{array}$ & $\begin{array}{c}0.331 * * * \\
(0.05)\end{array}$ & & $\begin{array}{c}0.048^{*} \\
(0.03)\end{array}$ & $\begin{array}{c}0.646^{* * *} * \\
(0.09)\end{array}$ \\
\hline $\mathbb{E}_{t} y_{i, t+2}$ & $\begin{array}{l}-0.015 \\
(0.14)\end{array}$ & $\begin{array}{l}-0.002 \\
(0.11)\end{array}$ & $\begin{array}{l}0.030 \\
(0.14)\end{array}$ & $\begin{array}{l}-0.041 \\
(0.12)\end{array}$ & $\begin{array}{c}-0.038 \\
(0.10)\end{array}$ & $\begin{array}{l}0.037 \\
(0.12)\end{array}$ \\
\hline$d o_{i, t-1}$ & $\begin{array}{c}-0.099 * * * \\
(0.01)\end{array}$ & $\begin{array}{c}-0.087 * * * \\
(0.01)\end{array}$ & $\begin{array}{c}-0.090 * * * \\
(0.01)\end{array}$ & $\begin{array}{c}-0.094 * * * \\
(0.01)\end{array}$ & $\begin{array}{c}-0.081 * * * \\
(0.01)\end{array}$ & $\begin{array}{c}-0.089 * * * \\
(0.01)\end{array}$ \\
\hline$f o_{i, t-1}$ & $\begin{array}{c}-0.142 * * * \\
(0.02)\end{array}$ & $\begin{array}{c}-0.144 * * * \\
(0.01)\end{array}$ & $\begin{array}{c}-0.149 * * * \\
(0.02)\end{array}$ & $\begin{array}{c}-0.170 * * * \\
(0.02)\end{array}$ & $\begin{array}{c}-0.170 * * * \\
(0.02)\end{array}$ & $\begin{array}{c}-0.179 * * * \\
(0.02)\end{array}$ \\
\hline$f p_{i, t-1}$ & $\begin{array}{c}-0.096 * * * \\
(0.02)\end{array}$ & $\begin{array}{c}-0.096 * * * \\
(0.02)\end{array}$ & $\begin{array}{c}-0.104 * * * \\
(0.01)\end{array}$ & $\begin{array}{c}-0.094 * * * \\
(0.02)\end{array}$ & $\begin{array}{c}-0.097 * * * \\
(0.02)\end{array}$ & $\begin{array}{c}-0.090 * * * \\
(0.01)\end{array}$ \\
\hline $\mathbb{E}_{t} E R_{i, t+2}$ & $\begin{array}{c}0.029 * * * \\
(0.01)\end{array}$ & $\begin{array}{c}0.028 * * * \\
(0.01)\end{array}$ & $\begin{array}{c}0.027 * * * \\
(0.01)\end{array}$ & $\begin{array}{c}0.038 * * * \\
(0.01)\end{array}$ & $\begin{array}{c}0.039 * * * \\
(0.01)\end{array}$ & $\begin{array}{c}0.039 * * * \\
(0.01)\end{array}$ \\
\hline$N F A_{i, t-1}$ & $\begin{array}{c}-0.014 * * * \\
(0.00)\end{array}$ & $\begin{array}{c}-0.015 * * * \\
(0.00)\end{array}$ & $\begin{array}{c}-0.014 * * * \\
(0.00)\end{array}$ & & & \\
\hline$C C_{i, t-1}$ & & & & $\begin{array}{c}-3.900 * * * \\
(1.10)\end{array}$ & $\begin{array}{c}-3.892 * * * \\
(1.00)\end{array}$ & $\begin{array}{c}-4.141 * * * \\
(1.09)\end{array}$ \\
\hline AIC Criterion & -8.547 & -8.581 & -8.640 & -8.612 & -8.611 & -8.626 \\
\hline No. of observation & 625 & 625 & 625 & 625 & 625 & 625 \\
\hline No. of countries & 25 & 25 & 25 & 25 & 25 & 25 \\
\hline Sample periods & $06: 2-18: 2$ & $06: 2-18: 2$ & $06: 2-18: 2$ & $06: 2-18: 2$ & $06: 2-18: 2$ & $06: 2-18: 2$ \\
\hline
\end{tabular}

Notes: IT=Interaction term model,PSTR=Panel Smooth Transition Regression and GPSTR=General Panel Smooth Transition Regression. $\mathbb{E}_{t}$ Debt $_{i, t+2}$ is two-year-ahead expected public debt to GDP ratio, $g(\cdot)$ is transition function, $\mathbb{E}_{t} y_{i, t+2}$ is two-year-ahead expected growth rate, $d o_{i, t-1}$ is the lagged domestic official sector holdings ratio, $f o_{i, t-1}$ the lagged foreign official sector holdings ratio, $f p_{i, t-1}$ is the lagged foreign private sector holdings ratio, $\mathbb{E}_{t} E x c h a n g e$ rate $e_{i, t+2}$ is the expected exchange rate depreciation in two-year horizon, $N F A_{i, t-1}$ is the lagged net foreign assets to GDP ratio and $C C_{i, t-1}$ is the lagged capital control dummy. The standard errors proposed by Driscoll and Kraay (1998) are reported in parentheses. ${ }^{* * *} \mathrm{p}<0.01,{ }^{*} \mathrm{p}<0.05,{ }^{*} \mathrm{p}<0.1$ 
Table 5: (Continued) Robustness check 5 and 6

\begin{tabular}{|c|c|c|c|c|c|c|}
\hline & $\longrightarrow$ & (R5) & $\longrightarrow$ & $\longrightarrow$ & (R6) & $\longrightarrow$ \\
\hline & IT & PSTR & GPSTR & IT & PSTR & GPSTR \\
\hline$L M_{F}$ nonlinearity test & 9.5 & 9.5 & 9.5 & 20.0 & 20.0 & 20.0 \\
\hline $\mathrm{p}$-value & $0.00 * * *$ & $0.00 * * *$ & $0.00 * * *$ & $0.00 * * *$ & $0.00 * * *$ & $0.00 * * *$ \\
\hline Location parameter $(c)$ & & 0.306 & 0.092 & & 0.292 & 0.093 \\
\hline Slope parameter $1\left(\gamma_{1}\right)$ & & 14.0 & -47.5 & & 12.3 & 0.0 \\
\hline Slope parameter $2\left(\gamma_{2}\right)$ & & & 5.8 & & & 5.0 \\
\hline $\mathbb{E}_{t} D e b t_{i, t+2}$ & $\begin{array}{l}-0.004 \\
(0.01)\end{array}$ & $\begin{array}{l}0.003 \\
(0.01)\end{array}$ & $\begin{array}{c}-0.096 * * * \\
(0.02)\end{array}$ & $\begin{array}{c}-0.019 * * \\
(0.01)\end{array}$ & $\begin{array}{l}-0.011 \\
(0.01)\end{array}$ & $\begin{array}{c}-0.186 * * * \\
(0.01)\end{array}$ \\
\hline $\mathbb{E}_{t}$ Debt $_{i, t+2} \cdot f p_{t-1}$ & $\begin{array}{c}0.101^{* * *} \\
(0.04)\end{array}$ & & & $\begin{array}{c}0.160 * * * \\
(0.03)\end{array}$ & & \\
\hline $\mathbb{E}_{t} D_{e b t_{i, t+2}} \cdot g(\cdot)$ & & $\begin{array}{l}0.044 \\
(0.03)\end{array}$ & $\begin{array}{c}0.206^{* * *} * \\
(0.03)\end{array}$ & & $\begin{array}{c}0.076^{* * * *} \\
(0.03)\end{array}$ & $\begin{array}{c}0.363 * * * \\
(0.03)\end{array}$ \\
\hline$S T R_{i, t}$ & $\begin{array}{c}0.388 * * * \\
(0.05)\end{array}$ & $\begin{array}{c}0.385 * * * \\
(0.04)\end{array}$ & $\begin{array}{c}0.381 * * * \\
(0.05)\end{array}$ & & & \\
\hline $\mathbb{E}_{t} \pi_{i, t+2}$ & & & & $\begin{array}{c}0.358 * * * \\
(0.13)\end{array}$ & $\begin{array}{c}0.351 * * * \\
(0.12)\end{array}$ & $\begin{array}{c}0.355^{* * *} * \\
(0.12)\end{array}$ \\
\hline $\mathbb{E}_{t} y_{i, t+2}$ & $\begin{array}{l}-0.060 \\
(0.12)\end{array}$ & $\begin{array}{l}-0.051 \\
(0.11)\end{array}$ & $\begin{array}{l}-0.022 \\
(0.10)\end{array}$ & $\begin{array}{l}0.087 \\
(0.12)\end{array}$ & $\begin{array}{l}0.097 \\
(0.12)\end{array}$ & $\begin{array}{l}0.127 \\
(0.12)\end{array}$ \\
\hline$d o_{i, t-1}$ & $\begin{array}{c}-0.081 * * * \\
(0.01)\end{array}$ & $\begin{array}{c}-0.070 * * * \\
(0.01)\end{array}$ & $\begin{array}{c}-0.072 * * * \\
(0.01)\end{array}$ & $\begin{array}{c}-0.069 * * * \\
(0.12)\end{array}$ & $\begin{array}{c}-0.053 * * * \\
(0.01)\end{array}$ & $\begin{array}{c}-0.053 * * * \\
(0.01)\end{array}$ \\
\hline$f o_{i, t-1}$ & $\begin{array}{c}-0.099 * * * \\
(0.02)\end{array}$ & $\begin{array}{c}-0.101 * * * \\
(0.02)\end{array}$ & $\begin{array}{c}-0.105 * * * \\
(0.01)\end{array}$ & $\begin{array}{c}-0.139 * * * \\
(0.02)\end{array}$ & $\begin{array}{c}-0.140 * * * \\
(0.02)\end{array}$ & $\begin{array}{c}-0.145 * * * \\
(0.02)\end{array}$ \\
\hline$f p_{i, t-1}$ & $\begin{array}{c}-0.088 * * * \\
(0.03)\end{array}$ & $\begin{array}{c}-0.086^{* * * *} \\
(0.02)\end{array}$ & $\begin{array}{c}-0.087 * * * \\
(0.01)\end{array}$ & $\begin{array}{c}-0.115^{* * * *} \\
(0.02)\end{array}$ & $\begin{array}{c}-0.116 * * * \\
(0.02)\end{array}$ & $\begin{array}{c}-0.116 * * * \\
(0.02)\end{array}$ \\
\hline $\mathbb{E}_{t} E R_{i, t+2}$ & $\begin{array}{l}0.002 \\
(0.01)\end{array}$ & $\begin{array}{l}0.003 \\
(0.01)\end{array}$ & $\begin{array}{l}0.001 \\
(0.01)\end{array}$ & $\begin{array}{c}0.045^{* * *} * \\
(0.01)\end{array}$ & $\begin{array}{c}0.046^{* * *} * \\
(0.01)\end{array}$ & $\begin{array}{c}0.043^{* * *} * \\
(0.01)\end{array}$ \\
\hline AIC Criterion & -8.800 & -8.796 & -8.805 & -8.649 & -8.651 & -8.657 \\
\hline No. of observation & 625 & 625 & 625 & 625 & 625 & 625 \\
\hline No. of countries & 25 & 25 & 25 & 25 & 25 & 25 \\
\hline Sample periods & $06: 2-18: 2$ & $06: 2-18: 2$ & $06: 2-18: 2$ & $06: 2-18: 2$ & $06: 2-18: 2$ & $06: 2-18: 2$ \\
\hline
\end{tabular}

Notes: IT=Interaction term model,PSTR=Panel Smooth Transition Regression and GPSTR=General Panel Smooth Transition Regression. $\mathbb{E}_{t}$ Debt $_{i, t+2}$ is two-year-ahead expected public debt to GDP ratio, $g(\cdot)$ is transition function, $\mathbb{E}_{t} \pi_{i, t+2}$ is two-year-ahead expected inflation, $\mathbb{E}_{t} y_{i, t+2}$ is two-year-ahead expected growth rate, $d o_{i, t-1}$ is the lagged domestic official sector holdings ratio, $f o_{i, t-1}$ the lagged foreign official sector holdings ratio, $f p_{i, t-1}$ is the lagged foreign private sector holdings ratio, $\mathbb{E}_{t}$ Exchange rate $_{i, t+2}$ is the expected exchange rate depreciation in two-year horizon, and $S T R_{i, t}$ is one-year zero coupon rate. The standard errors proposed by Driscoll and Kraay (1998) are reported in parentheses. ${ }^{* * *} \mathrm{p}<0.01,{ }^{*} \mathrm{p}<0.05,{ }^{*} \mathrm{p}<0.1$ 
Figure 9: Marginal impact of the expected public debt-to-GDP ratio on the interest rate (Baseline and robustness check)

IT

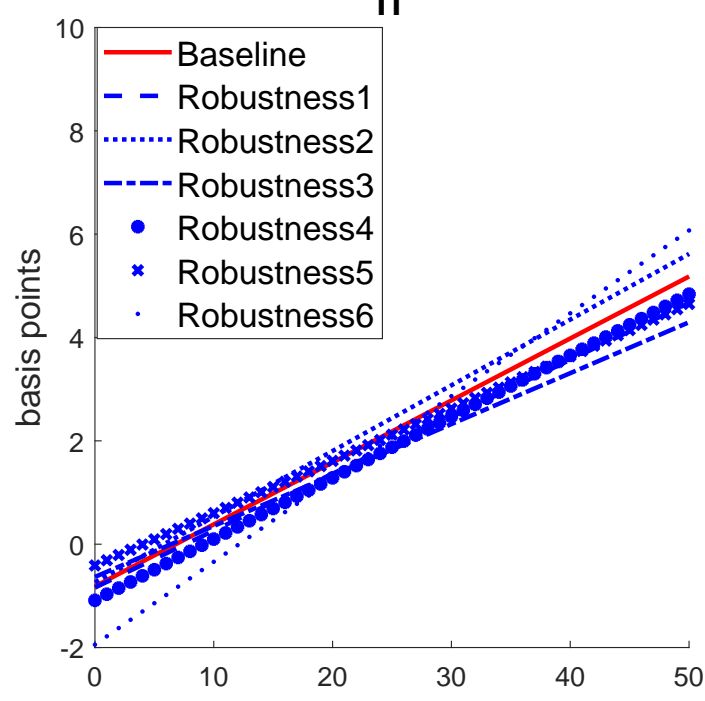

Share of the foreign private investors(\%)
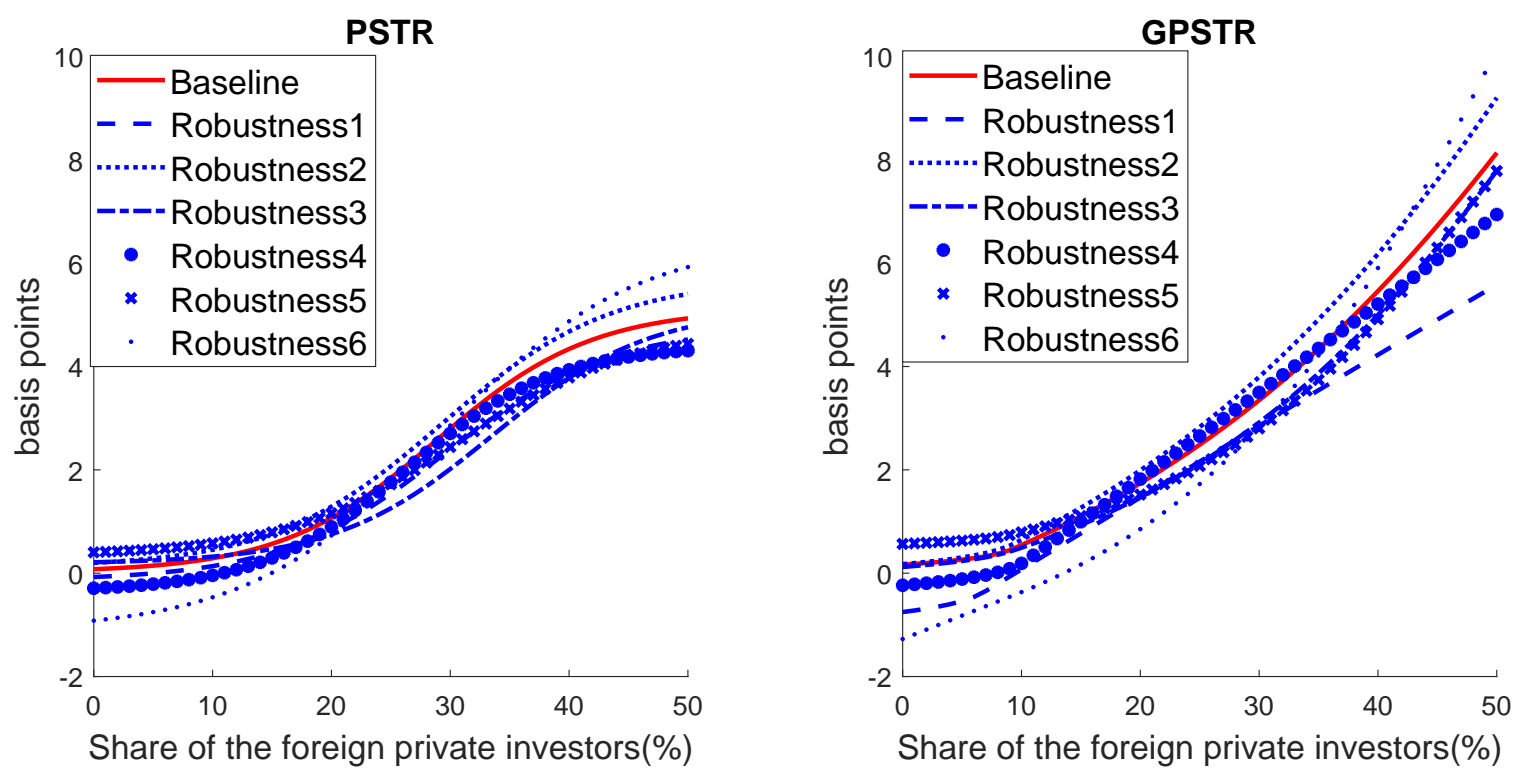

Notes: Basis points. The baseline and robustness 1-5 employ real forward interest rates as a dependent variable. The baseline equation includes the two-year-ahead expected public debt to GDP ratio, the two-year-ahead expected growth rate, the lagged domestic official sector holdings ratio, the lagged foreign official sector holdings ratio, the lagged foreign private sector holdings ratio and the expected exchange rate depreciation in two-year horizon. Robustness1: Controlling for US monetary condition. Robustness2: Excluding the expected exchange rate depreciation. Robustness3: Controlling for the net foreign assets position. Robustness4: Controlling for the capital control. Robustness5: Controlling for the short-term interest rate. Robustness6: Dependent variable: nominal interest rates. 
Table 6: Cross validations: comparison of out-of-sample forecast errors

\begin{tabular}{|c|c|c|}
\hline & $\begin{array}{c}\text { (1) IT vs. GPSTR } \\
\frac{M S E_{G P S T R}-M S E_{I T}}{M S E_{I T}} \times 100\end{array}$ & $\begin{array}{l}\text { (2) PSTR vs. GPSTR } \\
\frac{M S E_{G P S T R}-M S E_{P S T R}}{M S E_{P S T R}} \times 100\end{array}$ \\
\hline Baseline & $-7.2 \%$ & $-4.0 \%$ \\
\hline $\begin{array}{c}\text { Robustness check1 } \\
\text { (ControllingUS termpremium) }\end{array}$ & $-5.2 \%$ & $-4.0 \%$ \\
\hline $\begin{array}{c}\text { Robustness check2 } \\
\text { (excl. exchange ratedepreciation) }\end{array}$ & $-6.0 \%$ & $-3.0 \%$ \\
\hline $\begin{array}{c}\text { Robustness check3 } \\
\text { (Controlling net foreign assets) }\end{array}$ & $-4.4 \%$ & $-2.6 \%$ \\
\hline $\begin{array}{c}\text { Robustness check } 4 \\
\text { (Controlling capital control) }\end{array}$ & $-0.8 \%$ & $-3.7 \%$ \\
\hline $\begin{array}{c}\text { Robustness check5 } \\
\text { (Controlling short }- \text { term interest rate) }\end{array}$ & $-8.7 \%$ & $-4.8 \%$ \\
\hline $\begin{array}{c}\text { Robustness check6 } \\
\text { (Dependent variable: nominal interest rate) }\end{array}$ & $-8.2 \%$ & $-0.6 \%$ \\
\hline
\end{tabular}

Note: $M S E$ indicates mean squared error. $M S E=\frac{1}{N T} \sum_{i=1}^{N} \sum_{t=1}^{T}\left[\widetilde{y}_{i, t}-\widehat{\Psi}_{-i}\left(x_{i, t}^{*}\right)\right]^{2}$ where $\widehat{\Psi}_{-i}(\cdot)$ is computed by leaving out all observations of the $i$ th cross-section. 
Table 7: Comparison with other studies

\begin{tabular}{|c|c|c|c|c|}
\hline $\begin{array}{l}\text { (1) Marginal impact of } \\
\text { expected public debt on } \\
\text { government bond yields }\end{array}$ & $\begin{array}{l}\text { basis point } \\
\text { per } 1 \text { percent }\end{array}$ & Forecast data & Countries/Group & \\
\hline This study & $\begin{array}{l}0.9-2.0 \text { (the share of foreign investors is } 20 \text { percent) } \\
2.8-3.8 \text { (the share of foreign investors is } 30 \text { percent) } \\
\text { 4.2-6.2(the share of foreign investors is } 40 \text { percent) }\end{array}$ & IMF, OECD, EC, EIU & 11 AEs and $14 \mathrm{EMs}$ & \\
\hline Engen and Hubbard (2005) & 2.8 & $\mathrm{CBO}$ & U.S & \\
\hline Laubach (2009) & 3 to 4.4 & $\mathrm{CBO}$ & U.S & \\
\hline Gruber and Kamin (2012) & 0.4 to 1.3 & OECD & 19 OECD countries & \\
\hline Ichiue and Shimizu (2015) & 0.7 to 0.9 & OECD & 10 OECD countries & \\
\hline Jaramillo and Weber (2013) & 4 to 6 & EIU & 26 EMs & \\
\hline $\begin{array}{l}\text { (2) Marginal mpact of } \\
\text { the share of foreign investors } \\
\text { on government bond yields }\end{array}$ & $\begin{array}{l}\text { basis point } \\
\text { per } 1 \text { percent }\end{array}$ & Forecast data & Countries & Investor type \\
\hline Arslanalp and Poghosyan (2016) & -6.9 to -5.5 & IMF & 22 AEs & Foreign Official \\
\hline Ebeke and Lu (2015) & -10.6 to -6.5 & Actual data & 13 EMs & Foreign \\
\hline $\begin{array}{l}\text { (3) Estimated tipping points } \\
\text { for the impact of the increase in } \\
\text { foreign investors }\end{array}$ & $\begin{array}{r}\text { Threshold value of debt } \\
\text { to GDP ratio }\end{array}$ & Forecast data & Countries & Investor type \\
\hline \multirow[t]{2}{*}{ This study (Baseline) } & $\begin{array}{l}59 \text { percent (Expected gross public debt) } \\
\text { given that the share of foreign investors is } 30 \text { percent }\end{array}$ & IMF, OECD, EC, EIU & 11 AEs and 14 EMs & Foreign Private \\
\hline & $\begin{array}{l}91 \text { percent (Expected gross public debt) } \\
\text { given that the share of foreign investors is } 15 \text { percent }\end{array}$ & IMF, OECD, EC, EIU & $11 \mathrm{AEs}$ and $14 \mathrm{EMs}$ & Foreign Private \\
\hline Ebeke and Lu (2015) & 90 percent (Lagged external debt) & Actual data & 13 EMs & Foreign \\
\hline Ebeke and Lu (2015) & 21.5 percent (Lagged short-term debt) & Actual data & 13 EMs & Foreign \\
\hline
\end{tabular}

\footnotetext{
Notes: AEs=advanced economies
} and $\mathrm{EMs}=$ emerging markets. 


\section{Appendix}

\section{A.1 Linearity test}

Testing the null hypothesis $H_{0}: \beta_{0}=\beta_{1}$ can examine the linearity in the GPSTR model (3). However, this test is not standard since under $H_{0}$ the GPSTR model contains unidentified nuisance parameters(Hansen (1996)). Following Luukkonen et al. (1988) and Terasvirta (1994), we replace the transition function $g\left(f p_{i, t-1} ; \gamma_{1}, \gamma_{2}, c\right)$ with the first-order Taylor expansion around $\gamma_{1}=0$ and $\gamma_{2}=0$. The practical computation follows two steps.

- Step1. The linearized GPSTR model is given by

$$
\mathbb{E}_{t} L_{i, t+n}=\alpha_{i}+\beta_{0} \mathbb{E}_{t} \operatorname{Debt}_{i, t+n}+\beta_{1} \mathbb{E}_{t} \operatorname{Debt}_{i, t+n} \cdot T_{1}\left(g\left(f p_{i, t-1} ; \gamma_{1}, \gamma_{2}, c\right)\right)+\delta f p_{i, t-1}+\phi \mathbf{z}_{\mathbf{i}, \mathbf{t}}+\varepsilon_{i, t}
$$

where $T_{1}\left(g\left(f p_{i, t-1} ; \gamma_{1}, \gamma_{2}, c\right)\right)$ is the first-order Taylor approximation of the transition function $g\left(f p_{i, t-1} ; \gamma_{1}, \gamma_{2}, c\right)$ around $\gamma_{1}=0$ and $\gamma_{2}=0$. This auxiliary regression for testing linearity can be rewritten as

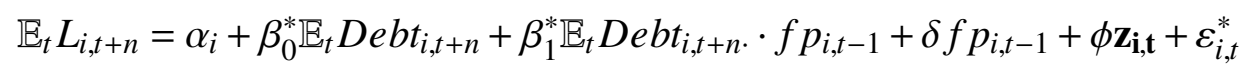

The sum of squared residuals is $S S R_{1}$.

- Step2. To test the null hypothesis is $H_{0}: \beta_{1}^{*}=0$, the approximate likelihood ratio of $H_{0}$ is based on

$$
L M_{F}=T N\left(S S R_{0}-S S R_{1}\right) / S S R_{0}
$$

where $S S R_{0}$ is the sum of squared residuals of the linear model $\mathbb{E}_{t} L_{i, t+n}=\alpha_{i}+\beta_{0} \mathbb{E}_{t}$ Debt $t_{i, t+n}+\delta f p_{i, t-1}+$ $\phi \mathbf{z}_{\mathbf{i}, \mathbf{t}}+\varepsilon_{i, t}$ and $S S R_{1}$ is that of the GPSTR model with two regimes.

If a p-value associated with $L M_{F}$ leads us to reject the null hypothesis, we employ the GPSTR model ${ }^{26}$.

\section{A.2 Derivatives of the transition function}

The derivatives of the transition function $g\left(f p_{i, t-1} ; \gamma_{1}, \gamma_{2}, c\right)$ is needed in order to calculate the sensitivity of the long-term interest rate to the increase in the share of foreign private investors in Table 1.

\footnotetext{
${ }^{26}$ González and Teräsvirta (2006) use Monte Carlo testing techniques for testing linearity against smooth transition models instead of being based on an auxiliary regression obtained by replacing the model under the alternative by approximations based on a Taylor expansion.
} 
For $f p_{i, t-1}-c \leqslant 0$

$$
\frac{\partial g\left(f p_{i, t-1} ; \gamma_{1}, \gamma_{2}, c\right)}{\partial f p_{i, t-1}}=\left\{\begin{array}{cc}
\frac{\exp \left(-\gamma_{1}^{-1}\left(\log \left(1-\gamma_{1}\left|f p_{i, t-1}-c\right|\right)\right)\right)}{\left(1-\gamma_{1}\left|f p_{i, t-1}-c\right|\right)\left[\exp \left(-\gamma_{1}^{-1}\left(\log \left(1-\gamma_{1}\left|f p_{i, t-1}-c\right|\right)\right)\right)+1\right]^{2}} & \gamma_{1}<0 \\
\frac{\exp \left(f p_{i, t-1}-c\right)}{\left[1+\exp \left(f p_{i, t-1}-c\right)\right]^{2}} & \gamma_{1}=0 \\
\frac{\exp \left(\gamma_{1}\left|f p_{i, t-1}-c\right|\right) \exp \left(\gamma_{1}^{-1}\left(\exp \left(\gamma_{1}\left|f p_{i, t-1}-c\right|\right)-1\right)\right)}{\left[\exp \left(\gamma_{1}^{-1}\left(\exp \left(\gamma_{1}\left|f p_{i, t-1}-c\right|\right)-1\right)\right)+1\right]^{2}} & \gamma_{1}>0
\end{array}\right.
$$

For $f p_{i, t-1}-c \geqslant 0$

$$
\frac{\partial g\left(f p_{i, t-1} ; \gamma_{1}, \gamma_{2}, c\right)}{\partial f p_{i, t-1}}=\left\{\begin{array}{cc}
\frac{\exp \left(\gamma_{2}^{-1}\left(\log \left(1-\gamma_{2}\left|f p_{i, t-1}-c\right|\right)\right)\right)}{\frac{\gamma_{1}}{\left(1-\gamma_{2}\left|f p_{i, t-1}-c\right|\right)\left[\exp \left(\gamma_{2}^{-1}\left(\log \left(1-\gamma_{2}\left|f p_{i, t-1}-c\right|\right)\right)\right)+1\right]^{2}}} & \gamma_{2}<0 \\
\frac{\exp \left(f p_{i, t-1}-c\right)}{\left[1+\exp \left(f p_{i, t-1}-c\right)\right]^{2}} & \gamma_{2}=0 \\
\frac{\exp \left(\gamma_{2}\left|f p_{i, t-1}-c\right|\right) \exp \left(-\gamma_{2}^{-1}\left(\exp \left(\gamma_{2}\left|f p_{i, t-1}-c\right|\right)-1\right)\right)}{\left[\exp \left(-\gamma_{2}^{-1}\left(\exp \left(\gamma_{2}\left|f p_{i, t-1}-c\right|\right)-1\right)\right)+1\right]^{2}} & \gamma_{2}>0
\end{array}\right.
$$


Table A.1: Sources and description of the data

\begin{tabular}{|c|c|c|}
\hline Variable names & Description & Sources \\
\hline Forward interest rate & $\begin{array}{l}\text { Zero coupon rate on treasury } \\
\text { securities in local currency }\end{array}$ & $\begin{array}{l}\text { Bloomberg and Author's calculations based on } \\
\text { Shiller et al. (1983). }\end{array}$ \\
\hline $\begin{array}{l}\text { Expected public debt } \\
\text { to GDP ratio }\end{array}$ & $\begin{array}{l}\text { 2-year-ahead projections for general } \\
\text { government debt to nominal GDP }\end{array}$ & $\begin{array}{l}\text { IMF World Economic Outlook, Article IV Consultations, } \\
\text { OECD Economic Outlook } \\
\text { European Commission European Economic Forecast } \\
\text { Economist Intelligence Unit }\end{array}$ \\
\hline Expected inflation & $\begin{array}{l}\text { 2-year-ahead projections for } \\
\text { headline inflation }\end{array}$ & \multirow{2}{*}{$\begin{array}{l}\text { Consensus Economics Consensus Forecast } \\
\text { IMF World Economic Outlook, Article IV Consultations, } \\
\text { OECD Economic Outlook } \\
\text { European Commission European Economic Forecast } \\
\text { Economist Intelligence Unit }\end{array}$} \\
\hline Expected growth rate & $\begin{array}{l}\text { 2-year-ahead projections } \\
\text { for real GDP growth rate }\end{array}$ & \\
\hline $\begin{array}{l}\text { Foreign private } \\
\text { or official holdings ratio } \\
\text { in emerging markets }\end{array}$ & $\begin{array}{l}\text { Foreign holdings share of central } \\
\text { government debt securities } \\
\text { denominated in local currency }\end{array}$ & Author's calculations based on Arslanalp and Tsuda (2014a) \\
\hline $\begin{array}{l}\text { Foreign private } \\
\text { or official holdings ratio } \\
\text { in advanced economies }\end{array}$ & $\begin{array}{l}\text { Foreign holdings share of general } \\
\text { government debt securities } \\
\text { denominated in local currency }\end{array}$ & $\begin{array}{l}\text { Author's calculations based on Arslanalp and Tsuda (2014b) } \\
\text { and BIS Debt Securities Statistics }\end{array}$ \\
\hline $\begin{array}{l}\text { Domestic central bank } \\
\text { holdings ratio }\end{array}$ & $\begin{array}{l}\text { Domestic central bank holdings share } \\
\text { of general government debt securities }\end{array}$ & Arslanalp and Tsuda (2014a) and Arslanalp and Tsuda (2014b) \\
\hline $\begin{array}{l}\text { Expected exchange rate } \\
\text { to US dollar }\end{array}$ & $\begin{array}{l}\text { The rate of change between } 2 \text {-year-ahead } \\
\text { and the current estimated exchange rate }\end{array}$ & $\begin{array}{l}\text { Author's calculations based on Consensus Economics } \\
\text { Consensus Forecast }\end{array}$ \\
\hline Treasury term premia & $\begin{array}{l}\text { Treasury term premia } \\
\text { based on Adrian and Crump (2013) }\end{array}$ & The website of Federal Reserve Bank of New York \\
\hline $\begin{array}{l}\text { Net foreign assets } \\
\text { to GDP ratio }\end{array}$ & $\begin{array}{l}\text { International Investment Position: } \\
\text { Assets minus liabilities }\end{array}$ & $\begin{array}{l}\text { IMF International Financial Statistics } \\
\text { Haver Analytics }\end{array}$ \\
\hline Capital control dummy & $\begin{array}{l}\text { Capital control for bond } \\
\text { inflow and outflow restrictions }\end{array}$ & Fernández et al. (2016) \\
\hline
\end{tabular}

